NBSIR 85-3195

\title{
Heat Release Rate Characteristics of Some Combustible Fuel Sources in Nuclear Power Plants
}

B.T. Lee

U.S. DEPARTMENT OF COMMERCE

National Bureau of Standards

Gaithersburg, MD 20899

July 1985

QC Sponsored in part by

100

U.S. Nuclear Regulatory Commission

.456

Washington, DC 20555

$85-3195$ 

NBSIR 85-3195

HEAT RELEASE RATE CHARACTERISTICS

OF SOME COMBUSTIBLE FUEL SOURCES IN NUCLEAR POWER PLANTS

B.T. Lee

U.S. DEPARTMENT OF COMMERCE

National Bureau of Standards

Gaithersburg, MD 20899

July 1985

Sponsored in part by

U.S. Nuclear Regulatory Commission

Washington, DC 20555

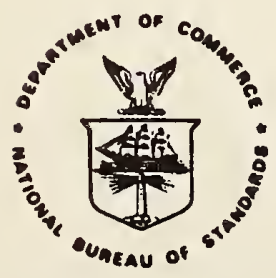

U.S. DEPARTMENT OF COMMERCE, Malcolm Baldrige, Secrotary NATIONAL BUREAU OF STANDARDS. Ernest Ambler, Director 

List of Tables... . . . . . . . . . . . . . . . . . . iv

List of Figures . . . . . . . . . . . . . . . . . . . . v v

Abstract . . . . . . . . . . . . . . . . . . . . . v vi

1. Introduction . . . . . . . . . . . . . . . . . . . . 1

2. Cable Tray Burn Characteristics . . . . . . . . . . . . . . 2

3. Trash Fire Burn Characteristics . . . . . . . . . . . . 5

4. Wood Fire Burn Characteristics . . . . . . . . . . . . . 6

5. Combustible Liquid Burn Characteristics . . . . . . . . . . 8

5.1 For Combustible Fluid Depth $>20 \mathrm{~mm}$. . . . . . . . . . 9

5.2 Finite Depth Spills Opaque to Thermal Radiation . . . . . . . 11

5.3 Finite Depth Spills Transparent to Thermal Radiation . . . 12

6. Summary . . . . . . . . . . . . . . . . . . 13

7. References . . . . . . . . . . . . . . . . . . . 14 
Table 1. Heat Release Rate Per Unit Area and Heat of Combustion for Flaming Fire of Cable Samples in Normal Air at $60 \mathrm{~kW} / \mathrm{m}^{2}$

Table 2. Simulated Trash Fire Experiments at Sandia National Labortories

Table 3. Ignition and Flame Spread Characteristics Under Constant Irradiance Conditions

Table 4. Rate of Heat Release per Unit Area for Selected Wood Products

Table 5. Unconfined Spill Depths for Hydrocarbon Liquids on EpoxyCoated Concrete and Steel

Table 6. Data for Large Pool Burning Rate Estimates

Table 7. Radiation Fraction of Combustion Energy for Hydrocarbon Pool Fires 
F1gure 1. Laboratory-Scale Flammability Apparatus

Figure 2. Horizontal Tray Test Setup 25

Figure 3. Mixed Tray Test Setup 26

Figure 4. Tray Surface Area Over Fire-Affected Cables Versus Burning Rate for PE/PVC Cables

F1gure 5. $\dot{Q}_{m}$ Versus $\dot{Q}_{A}$

Figure 6. Fire Involved Area Versus Time 29

Figure 7. Rate of Fire Coverage Versus Rate of Heat Release 30

Figure 8. Trash Fires 31

Figure 9. Trash Fires 32

Figure 10. Fire Tests of Piles of Clothes and Fabrics 33

Figure 11. Heat Release Rate Correlation with Size of Trash Fire 34

Figure 12. Heat Release Rate Correlation with Size of Trash Fire 35

Figure 13. Envelope Containing All of the Observed Heat Release Rate Curves for Trash Fires 36

Figure 14. Correlation of Velocity with Flux 37

Figure 15. Envelope Containing Velocity Versus Flux Data for Wood Products 38

Figure 16. Average Maximum Burning Rate vs Pile Height 39

Figure 17. Heat Release Rate for Single Stacks of Wood Pallets 40

Figure 18. Measured Surface Temperature of an Opaque, Semiinfinite Medium Compared with Theory Using Three Different Values of Net Flux of $13.8,8.9$ and 6.8 $\mathrm{kW} / \mathrm{m}^{2}$ and An External Flux of $13.8 \mathrm{~kW} / \mathrm{m}^{2}$

Figure 19. Measured Surface Temperature (Shaded Region) of Four Semi-transparent, semi-infinite, Hydrocarbon Liquids Compared with Theory Using a Net Flux of $10 \mathrm{~kW} / \mathrm{m}^{2}$ and An External Flux of $13.8 \mathrm{~kW} / \mathrm{m}^{2}$

Figure 20. Comparison of Theory and Experiment for Net Flux of $15.6 \mathrm{~kW} / \mathrm{m}^{2}$ and An External Flux of $26 \mathrm{~kW} / \mathrm{m}^{2}$

Figure 21. Comparison of Experiment and the Range Predicted by two Theoretical Limits for An Unconfined Spill of Pennzoil 30-HD on a Steel Substrate

Figure 22. Unconfined Spill of Pennzoil 30-HD on An EpoxyCoated Concrete Substrate 
A major risk to a nuclear power plant is the possibility of serious fire. There is a need to know the heat release rate behavior of combustible fuels in the plant in order to help reduce the fire threat to these facilities. Heat release rate characteristics of cable tray fires and some of the associated potential external ignition sources are discussed. Existing correlations are given to determining the time to ignition and the subsequent heat release rate of spills and pools of flammable liquids. Approximate correlations are developed for heat release rate for trash fires as a function of fire size and for one particular cable tray array arrangement as a function of the type of cable. In addition, a scheme is given for calculating the heat release rate from wood fuel fires.

key words: cable trays; fire safety; flammability; flammable liquids; heat release rate; ignition, liquid spills; nuclear power plants; pool fires; small-scale fire tests; trash; wood 


\subsection{Introduction}

Cable fires pose a serious fire hazard to a nuclear power plant. In 1975 a major cable fire shut down the world's largest operating nuclear plant, the Browns Ferry Nuclear Facility. It is generally agreed that ignition and subsequent fire involvement of cables in an utility plant would probably occur as a consequence of exposure to an external fire rather than from self-heating due to overloading or short-circuiting of the cables. External fires could be associated with a spill of flammable liquid, with a quantity of trash, with wood fuel in the form of boards, ladders, scaffolding, pallets, etc., or with a combination of such combustible sources.

The U.S. Nuclear Regulatory Commission is interested in identifying data and modeling or predicting techniques that can be used to extend the existing burn characteristics of cables and of such "first item" burn sources. This is one of the tasks in support of the Risk Methodology Integration and Evaluation Program (RMIEP) for the U.S. Nuclear Regulatory Commission. Other tasks of the RMIEP program involve the identification of usable models for the activation of detection and suppression devices, the identification of candidate room fire models for use in the RMIEP program, and the identification of areas where the modeling capability can be substantially enhanced for future nuclear power plant risk analyses. These other tasks are not addressed further in this report.

This report summarizes current information on the heat release rate characteristics of power cables and some of the associated potential external ignition sources. It includes the development of approximate correlations for heat release rate for trash fires as a function of fire size and for one particular cable tray array arrangement as a function of the type of cable. In addition, a scheme is presented for calculating the heat release rate from wood fuel fires. 


\subsection{Cable Tray Array Burn Characteristics}

A review of the literature on cable tray fires indicated that there were no reliable prediction models for the rate of heat release, nor were there direct heat release rate data available, on the burning of full-scale or intermediatescale cable tray arrays. This finding was consistent with a review of the subject by Nowlen [1]. Nowlen [2] has estimated the heat release rate from a fire test of two vertical cable trays burning over a 5 gal heptane fire based on heat loss measurements from the room. However, he did not separate the relative contribution due to the cables alone from that portion of the heat release rate due to the heptane. Hasegawa, et al, [3] attempted unsuccessfully to measure directly the heat release rate of cables burning in a single vertical array. They were able to measure weight loss which can be used to calculate the heat release rate. Unfortunately, extrapolation of data from fire tests of one or two cable trays to large tray array fires is hopelessly complicated by an inadequate understanding of fire-spread and thermal feedback among cable trays and the effect of vitiated air within the array.

Weight loss data have also been measured by Sumitra [4] in a series of intermediatescale fires involving arrays of 12 to 15 cable trays. This data together with actual heats of combustion for the cables would result in heat release rates for these fires. The heat of combustion and the unit area heat release rate of a variety of cable samples, including those used in Sumitra's tests, have been measured by Tewarson [5] with his laboratory-scale test shown in Figure 1 for the flaming mode of combustion under an irradiance exposure of $60 \mathrm{kw} / \mathrm{m}^{2}$. This data is given in Table 1 . With such limited information, the approach adopted here was to base a prediction scheme on a correlation of Sumitra's data with Tewarson's laboratory-scale data and to use the latter, in turn, to help predict array fire behavior for other types of cables.

Sumitra used two test arrangements using open ladder type of trays. For tests 1-14 with just horizontal trays, the array of twelve trays shown in Figure 2 was used. For tests 15-17, a mixed arrangement of twelve horizontal trays and 
three vertical trays, shown in Figure 3, was used. As indicated in Figures 2 and 3, a pan of heptane served as the ignition source. The estimated area of fire involvement in the trays at the time of extinguishment was given by Sumitra for tests 5 to 9 and 13 to 16 . Fire affected areas were also given for tests 10 and 11 where the fire self-extinguished. The fire involved area reported in each case was not the sum of the affected surface area of each individual cable but rather the exposed tray surface area over the fire affected cables. For example, each of the $2.44 \times 0.46 \mathrm{~m}$ open trays had a maximum fire involvement area of $1.12 \mathrm{~m}^{2}$ on the top, and $1.12 \mathrm{~m}^{2}$ on the bottom. When the burning rate at the time of extinguishment was plotted as a function of the fire involved area for the PE/PVC cables in Figure 4, the burning rate was found to vary linearly with the area of involvement. The burning rates at extinguishment were measured between 8 and 15.5 minutes, well beyond the duration of the heptane ignition source fires which burned out between 6 and 6.8 minutes.

The rate of heat release can be calculated either with the burning rate or with the fire involved surface area using the following equations:

$\dot{\mathrm{Q}}_{\mathrm{m}}=\dot{\mathrm{m}} \mathrm{H}_{\mathrm{T}} \mathrm{X}_{\mathrm{A}}$
$\dot{\mathrm{Q}}_{\mathrm{A}}=\dot{\mathrm{q}}^{\prime \prime} \mathrm{A}$

$\dot{Q}_{m}$-- Rate of heat release based on mass loss (kw)

$\dot{Q}_{A}$-- Rate of heat release based on pyrolysis area (kw)

$\dot{\mathrm{m}}$-- Rate of mass loss $(\mathrm{kg} / \mathrm{s})$

$\mathrm{H}_{\mathrm{T}}$-- Net heat of complete combustion $\left(\frac{\mathrm{kJ}}{\mathrm{g}}\right)$

$x_{A}--$ Combustion efficiency

$\dot{q}^{\prime \prime}$-- Rate of heat release per unit area from Laboratory test $\left(\mathrm{kW} / \mathrm{m}^{2}\right)$

A -- Pyrolysis area $\left(\mathrm{m}^{2}\right)$

The quantity $\dot{q}^{\prime \prime}$ and the product $\mathrm{H}_{\mathrm{T}} \mathrm{X}_{\mathrm{A}}$ measured by Tewarson are given in Table 1 under the headings of actual heat release rate per unit area and actual heat of combustion. $\dot{Q}_{m}$ is plotted against $\dot{Q}_{A}$ in Figure 5 for tests 5 to 9 and 13 to 16. The correlation shows that 
The cable materials PE/PVC, Hypalon, and silicone/asbestos indicated in Figure 5 correspond to cable samples 5, 8, and 22 in Table 1. The cable tests with the PE/PVC and with the silicone/asbestos used an extra tight packing arrangement. The Hypalon cable tests used packing arrangements ranging from loose (test 11) to extra tight (test 10). However, both tests 10 and 11 had burning rates of only about $0.1 \mathrm{~kg} / \mathrm{min}$ with predominantly scorching rather than pyrolysis of the fire affected areas by the heptane ignition source. Consequently, these two tests were not considered for the correlation in Figure 5. Tests 13 and 14 with the Hypalon cables in a different loose arrangement exhibited more vigorous burning rates of 6.6 and $3.3 \mathrm{~kg} / \mathrm{min}$. Sumitra stated that for unknown reasons, the Hypalon was difficult to ignite. Given this erratic behavior for the Hypalon cables, it was decided to consider only the worst case, test 13, for the Hypalon cables in the correlation in Figure 5.

Figure 6 shows the estimated area of fire involvement plotted against time of extinguishment for the three cable types. The slope of each line from Figure 6, or rate of fire coverage, is then plotted versus Tewarson's unit area heat release rate values from his laboratory test apparatus in Figure 7. The approach used for Figure 7 was similar to that adopted by Parker [6] where it was assumed that the flame area in the ASTM E 84 tunnel test was proportional to the total rate of heat production.

Figure 7 can, in turn, be used to estimate the rate of fire coverage for other types of cables tested in Tewarson's apparatus. The resulting estimated history for the pyrolyzing area, when multiplied with $\dot{q}^{\prime \prime}$ from Table 1 , gives $\dot{Q}_{A}$ versus time. Equation 3 then can be used to obtain $Q_{m}$ as a function of time. This prediction method applies only to cable array arrangements, cable packing densities, and exposure fires similar to those tested by Sumitra. Hasegawa, et al, [3] for instance, found that cable packing density could significantly affect the burning rate of cable tray fires. Thus, use of the method for significantly different situations may not be appropriate and would at best give only an approximation for the heat release rate of such cable tray fires. 
Trash fires by Van Volkinburg, et a1 [7], Lee [8], and Cline, et al [9] were considered for this analysis. The data is given on Figures 8, 9, 10 and Table 2. Van Volkinburg's fires were conducted in a room such that re-radiation from the hot gases and heated surfaces could reinforce the burning behavior of the fuel. Peak ceiling temperatures ranged from 95 to $390^{\circ} \mathrm{C}$ for the trash fires shown in Figures 8 and 9. This reinforcement would make the burning rate somewhat high and thus conservative for hazard analysis. Excluded from Figure 8 was a fire involving a 121 liter combustible wastebasket filled with 72 milk cartons, which exceeded a celling temperature of $400^{\circ} \mathrm{C}$ in a little over $60 \mathrm{~s}$ and exceeded $300^{\circ} \mathrm{C}$ in $180 \mathrm{~s}$. Radiatlve feedback varies as temperature ralsed to the fourth power. At such elevated temperatures, the radiative feedback would cause the burning rate to be excessively high and would be too unrealistic for free-burning hazard analysis. It should be noted that the temperature of $330^{\circ} \mathrm{C}$ indicated at $120 \mathrm{~s}$ for that fire was in error in Volkinburg's report and should have been about $600^{\circ} \mathrm{C}$ to be consistent with its heat release rate curve. Discussions with Fisher [10], one of the authors, verified that conclusion.

In order to relate the heat release rate from the burning trash with the size of the fire, an effective diameter for each trash fire had to be determined. Obviously, only data where the size of the container was known could be used. An examination of three waste container sizes of $30 \mathrm{gal}, 20 \mathrm{gal}$ and 8 gal at the NBS fire test facility indicated an aspect ratio of height to diameter of about 1.25, This ratio was assumed for Van Volkinburg's and Cline's data. Lee's data were for $0.3 \mathrm{~m}$ high piles of clothes and fabrics on the floor and the actual pile diameters were used. For situations where two and three similar bags were piled together, the effective diameters were taken to be $\sqrt{2}$ and $\sqrt{3}$ times the diameter of one bag, respectively. Figure 11 gives a correlation of the trash fire data. The quantity $A$ is the area of the container opening plus the exterior side area of a combustible container. For example, a 32 gal container has $0.19 \mathrm{~m}^{2}$ on the top and $0.96 \mathrm{~m}^{2}$ on its sides. The peak unit area heat release rate decreased with increasing diameter much like that for liquid pool fires [11] in the laminar range of burning. For pool 
fires, the rates increase with size for diameters between 0.3 and $1.0 \mathrm{~m}$. This behavior was absent in Figure 11. One important parameter lacking in the correlation was packing density. The trash fires could be plotted as in Figure 12 where two curves corresponding to packing densities of about 30 and $100 \mathrm{~kg} / \mathrm{m}^{3}$ were observed. Lee's data had rates which were much lower than the curve for the $30 \mathrm{~kg} / \mathrm{m}^{3}$ packing density. The reason for this low rate was that fire penetration into the piles of clothes and fabrics was limited by the pile height of $0.3 \mathrm{~m}$. Consequently, pyrolysis of the combustibles at depths greater than $0.3 \mathrm{~m}$, which certainly happened for the other trash fires, could not occur and contribute to these fires. Without more experimental data on the role of packing density, interpolation and extrapolation of the data in Figure 12 are difficult.

Figure 13 shows an envelope containing essentially all of the observed heat release rate curves for the trash fires in Figure 11. The curve in Figure 13 was somewhat low between 6 and 12 minutes for the rubbish bag fire and for Lee's data, but the discrepancies were not serious. Figure 13 and Figure 11 may be used with the awareness that the correlation was fairly crude and that heat release rates might increase with diameter when an effective diameter exceeded a value of about $1.0 \mathrm{~m}$.

\subsection{Wood Fire Burn Characteristics}

Fires might not propagate or could spread slowly, rapidly, or almost spontaneously on a wood surface depending on the incident flux environment. The effect of incident flux on flame spread on simple wood configurations such as boards and even scaffolding is known. Once part of a board has ignited, involvement of the vertical surface directly above the ignition area would be rapid. As an approximation, such vertical flame involvement could be assumed to be instantaneous. Flame spread in the horizontal, lateral, and downward directions can not occur unless a critical flux level for that material has been achieved. Quintiere and Harkleroad [12] have tabulated this critical flux for flame spread, $\dot{q}_{0, s}^{\prime \prime}$, in Table 3 for a variety of wood products. They also derived the following expression for flame spread velocity: 
$v^{-1 / 2}=c\left[\dot{q}_{0,1 g}^{\prime \prime}-\dot{q}_{e}^{\prime \prime}(x) \cdot F(t)\right]$

where

$$
\begin{aligned}
F(t) & =1-\exp \left(\frac{h^{2} t}{k \rho c}\right) \operatorname{erfc} \sqrt{\frac{h^{2} t}{k \rho c}} \\
& =\left\{\begin{array}{l}
b \sqrt{t}, t \leq t_{m} \\
1, t>t_{m}
\end{array}\right.
\end{aligned}
$$

and where V-flame spread velocity

c - specific heat

C - flame spread parameter

h - heat loss coefficient

k - thermal conductivity

$\dot{q}_{o, i g}$ - critical flux for ignition

$\dot{q}_{e}^{\prime \prime}(x)$ - external radiant flux

$\mathrm{b}$ - parameter in equation

$t$ - time

$t_{m}$ - characteristic equilibrium time

$\rho$ - density

Use of $F(t)$ accounted for the transient heating of the solid. The quantities $\dot{q}_{o, s}^{\prime \prime}, c, \dot{q}_{o, i g}^{\prime \prime}, b$, and $t_{m}$ are given in Table 3 for several wood products. A typical plot of equation 4 is given in Figure 14, where the above quantities are further described. The quantity $\dot{q}_{0, i g}^{\prime \prime}$ can also be obtained by indirect measurement by extrapolating the data in Figure 4 to zero velocity. These extrapolated values for $\dot{q}_{o}^{\prime \prime}$,ig are given in Table 3 under the heading of Number 2 . An envelope covering the flame spread velocity versus flux data for the wood products listed in Table 3 is given in Figure 15.

Once the area of fire involvement has been determined from flame spread considerations, then it can be multiplied by its heat release rate per unit area. Values for the latter are given by Chamberlain [13] in Table 4. As for 
the radiative and convective components of wood fires, Atreya [14] has determined these to be 23 and 77 percent, respectively, of the total heat release from the fire.

In many industrial and power plant facilities more complex configuration wood fuels such as pallets may be present. Krasner [15] has studied the burning characteristics of $4 \mathrm{ft} \times 4 \mathrm{ft} \times 5.5$ in pallets weighing 70 pounds each individually as well as in multiple pallets piled in a single stack. The average maximum burning rate, defined by Krasner to be the observed relatively constant rate of maximum burning over a four to five minute period, is given in Figure 16 as a function of height of the stack of pallets. Alpert and Ward [16] presented the heat release rate histories for several stack heights. Their data is given in Figure 17. From Figure 16, a 4 foot high stack has a maximum burning rate of about $43 \mathrm{lb} / \mathrm{min}$, which when multiplied with a heat of combustion value of about $7500 \mathrm{Btu} / \mathrm{lb}$, results in the 4 minute average maximum value of about $5400 \mathrm{Btu} / \mathrm{s}$ in Figure 17.

\subsection{Combustible Liquid Burn Characteristics}

Accidental fires with flammable liquids could occur with the liquid exposed in an opened container or with the liquid spilled on a surface. With a spilled liquid, the fuel may be confined or unconfined. In general, the liquid depth in a confined spill is expected to be greater than in an unconfined spill. For unconfined spills on a perfectly level floor, the time for the liquid to spread depends on the liquid viscosity and the roughness of the floor. The final depth depends on the surface tension of the liquid and on the contact angle between the liquid and the substrate.

Modak [17] has determined unconfined spill depths for hydrocarbon liquids on epoxy-coated concrete and steel floors. This data is given in Table 5. For pools of flammable liquids, Babrauskas [18] recommended that the burning rate $\dot{\mathrm{m}}^{\prime \prime}$ for pools with diameters greater than $0.2 \mathrm{~m}$ be given by 


$$
\dot{\mathrm{m}}^{\prime \prime}=\dot{\mathrm{m}}_{\infty}^{\prime \prime}\left(1-\mathrm{e}^{-\mathrm{k} \beta D}\right)
$$

and the heat release rate be given by

$$
\dot{q}=\Delta h_{c} \cdot \dot{m}^{\prime \prime} \cdot A
$$

where:

$$
\begin{aligned}
& A=\text { pool area }\left(\mathrm{m}^{2}\right) \\
& D=\text { pool diameter }(\mathrm{m}) \\
& \Delta \mathrm{h}_{\mathrm{c}}=\text { heat of combustion }(\mathrm{kJ} / \mathrm{kg}) \\
& \mathrm{k}=\text { extinction coefficient }\left(\mathrm{m}^{-1}\right) \\
& \dot{\mathrm{m}}^{-1} \text { pool mass loss rate }\left(\mathrm{kg} / \mathrm{m}^{2} / \mathrm{s}\right) \\
& \dot{\mathrm{m}}_{\infty}=\text { infinite-diameter pool mass loss rate }\left(\mathrm{kg} / \mathrm{m}^{2} / \mathrm{s}\right) \\
& B=\text { mean beam length corrector }(-)
\end{aligned}
$$

Values for the above quantities are given in Table 6 .

The time to pool ignition (attainment of fire point) can be obtained from equations by Modak [17], which relate temperature rise of the pool to incident flux and exposure time. For ease of reference, the equation numbers and the numbering of figures used by Modak were adopted for this part of the report.

\subsection{For combustible fluid depth $>20 \mathrm{~mm}$,}

The surface temperature rise is given by

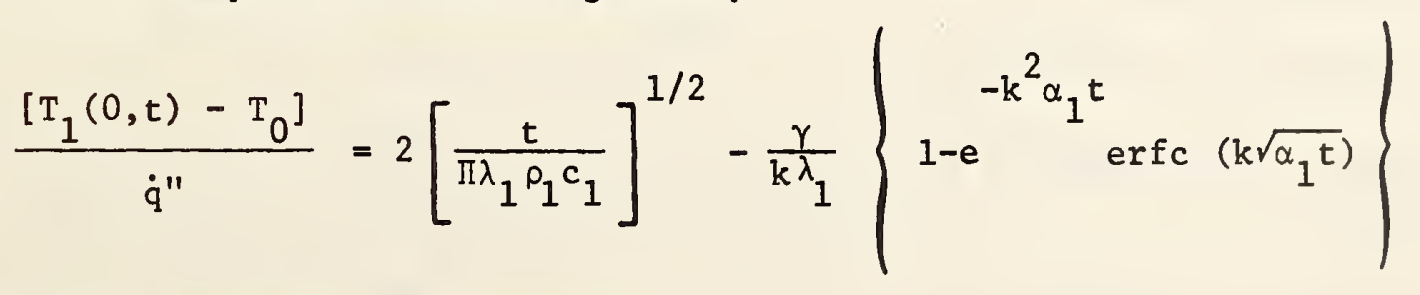

where: To $=$ the ambient temperature

$t=$ the time

$1-\gamma=$ the surface layer absorption

$k=$ the absorption coefficient 
$\dot{q}^{\prime \prime}=$ the net flux (approx. $65 \%$ of incident flux)

$\lambda=$ the thermal conductivity

$\rho_{1} c_{1}=$ the volumetric heat capacity of the fluid

$\Pi=3.14$

and

where $\alpha_{1}=\lambda_{1} / \rho_{1} c_{1}$ is the thermal diffusivity of the oil. The first term in Eq. 8 represents the classical solution for a non-transparent $(\gamma=0$ or $k \rightarrow \infty)$ medium:

$$
\Delta \mathrm{T}=2 \dot{q}^{\prime \prime}\left[\frac{\mathrm{t}}{\pi \lambda_{1} \rho_{1} c_{1}}\right]^{1 / 2}
$$

where $\Delta \mathrm{T}=\left(\mathrm{T}_{1}(0, t)-\mathrm{T}_{0}\right)$ is the surface temperature rise above ambient.

In the use of his equations, Modak recommended that the following properties be used for hydrocarbon liquids and typical concrete or steel floors:

PROPERTIES OF HYDROCARBON LIQUIDS*

$(300-600 \mathrm{~K})$

Thermal conductivity

125

$\lambda_{1}, \mathrm{~mW} /(\mathrm{m} \cdot \mathrm{K})$

Volumetric heat

capacity $\rho_{1} \mathrm{c}_{1}, \mathrm{MJ} /\left(\mathrm{m}^{3} \cdot \mathrm{K}\right)$

Surface layer absorption

0.45

$(1-\gamma)$

Absorption coefficient, 48 $\mathrm{k}, \mathrm{m}^{-1}$

*Values representative of most hydrocarbon fluids 


\begin{tabular}{lcc}
\hline & $\begin{array}{c}\text { Thermal Conductivity } \\
\lambda_{2}, \mathrm{~W} /(\mathrm{m} \cdot \mathrm{K})\end{array}$ & $\begin{array}{c}\text { Volumetric Heat Capacity } \\
\rho_{2} \mathrm{c}_{2}, \mathrm{MJ} /\left(\mathrm{m}^{3} \cdot \mathrm{K}\right)\end{array}$ \\
& 1.8 & 2.10 \\
$\begin{array}{l}\text { Concrete } \\
(\text { at } 373 \mathrm{~K})\end{array}$ & 46 & 3.62 \\
$\begin{array}{l}\text { Stee1 } \\
(\text { at } 300 \mathrm{~K})\end{array}$ & &
\end{tabular}

In his comparison of theory with experiment, given in Figures 18,19 , and 20 , there was good agreement when the net flux $\dot{q} "$ was assumed to be approximately 65 percent of the incident flux.

\subsection{Finite depth spills opaque to thermal radiation}

The time-dependent temperature rise over ambient, $\Delta T$, of the liquid surface is

$$
\Delta T=2 \dot{q}^{\prime \prime}\left(\frac{t}{\pi \lambda_{1} \rho_{1} c_{1}}\right)^{1 / 2}\left[1+2 \sqrt{\pi} \sum_{n=1}^{\infty} \sigma^{n} \operatorname{ferfc}\left(\frac{\mathrm{nd}}{\sqrt{\alpha_{1} t}}\right)\right]
$$

Here, $d$ is the depth of the spill and $\sigma$ is the ratio $(1-m) /(1+m)$ where $m$ is defined by

$$
m=\left(\lambda_{2} \rho_{2} c_{2} / \lambda_{1} \rho_{1} c_{1}\right)^{1 / 2}
$$

and $\lambda_{2} \rho_{2} c_{2}$ is a property of the substrate

Equation 10 shows some familiar features: for large values of the parameter $\left(\frac{d}{\sqrt{\alpha_{1} t}}\right)$, Eq. 10 yields the familiar solution for an opaque semi-infinite spill. 
For (thin spil1s) $\frac{d}{\sqrt{\alpha_{1} t}} \rightarrow 0, E q \cdot 10$ reduces to:

$$
\Delta \mathrm{T}=2 \dot{\mathrm{q}}^{\prime \prime}\left(\frac{\mathrm{t}}{\pi \lambda_{2}{ }^{\rho} \mathrm{c}_{2}}\right)^{1 / 2}
$$

Equation 11 implies that the temperature response of the thin spill is essentially the same as the surface temperature response of the semi-infinite substrate over which the (thin) layer of oil is spilled.

\subsection{Finite depth spills transparent to thermal radiation}

The surface temperature rise is given by

$$
\Delta T=\frac{4 \dot{q}^{\prime \prime}}{\sqrt{\lambda_{1} \rho_{1} c_{1}}}\left(\frac{1}{1+\mathrm{m}}\right) \sqrt{\mathrm{t}} \sum_{\mathrm{n}=0}^{\infty} \sigma^{\mathrm{n}} \operatorname{ierfc}\left[\frac{(2 \mathrm{n}+1) \mathrm{d}}{2 \sqrt{\alpha_{1} \mathrm{t}}}\right] \text {. }
$$

Not unexpectedly, Eq. 12 reduces to Eq. 11 for thin spills $\left(\frac{d}{\sqrt{\alpha_{1} t}} \rightarrow 0\right)$.

This implies that, for thin spills, both opaque as well as transparent models yield the same solution. For thick spills, the transparent model is not a very meaningful model: Eq. 12 shows that for the thick case $\Delta T$ tends to zero. The semi-transparent, semi-infinite model assumed for equation 8 is more suitable for thick spills.

Modak compared theory with experiment for finite depth spills in Figures 21 and 22 with the conclusion that the opaque solution is better suited for the finite spill fires studied.

As for the radiation fraction of the combustion energy for hydrocarbon pool fires, Mudan [19] has studied the problem with the results given in Table 7. 
1. There is currently no direct heat release rate data available on the burning of full-scale or intermediate-scale cable tray arrays. However, existing weight loss data, measured in a series of intermediate-scale fires, was used to estimate heat release rate(s). The latter were used, in turn, to develop a prediction scheme for fullscale fire behavior based on laboratory-scale heat release rate data for cables. For cable array arrangements, cable packing densities, and exposure fires significantly different from those used for the prediction scheme, the use of this method may not be appropriate and would at best give only an approximation for the heat release rate of such cable tray fires.

2. Trash fire data was reviewed, and the peak unit area rate of heat release from these fires was correlated with size of the trash container. Packing density was shown to be significant in the burning behavior of trash. A generalized heat release rate history, based on the peak unit area rate of heat release, was suggested for trash fires.

3. A method for predicting the heat release rate history of simple wood fuel configurations was given based on existing flame spread data correlations and unit area rate of heat release data from laboratory fire tests. For more complex configuration wood fuels, the burning characteristics of wood pallets could be used as an approximation.

4. A review of the literature on flammable liquid spill fires indicated that existing theory was adequate for roughly predicting the time to ignition for spills of varying size, thickness, and opacity and the subsequent rate of heat release. 
1. Nowlen, S.P., "A Literature Review of Quantitative Information on the Behavior of Materials in Fire as Related to Nuclear Power Plant Fires". Sandia National Laboratory, Albuquerque, N.M. Rough draft June 29, 1984.

2. Nowlen, S.P., "Heat Release Rates During the Sandia/U.I. 20 Foot Separation Tests". Sandia National Laboratories, Albuquerque, N.M. Letter Report June 1984.

3. Hasegawa, H.K., et al, Fire Protection Research for DOE Facilities: FY 82 Year - End Report. Lawrence Livermore National Laboratory, University of California, Livermore, California; September 2, 1983.

4. Sumitra, P.S., "Categorization of Cable Flammability. Intermediate-Scale Fire Tests of Cable Tray Installations". Factory Mutual Research Corporation, Norwood, Mass. Interim Report NP-1881 Research Project 1165-1; August 1982.

5. Tewarson, A., and Lee, J.L., and Pion, R.F., "Categorization of Cable Flammability. Part I: Experimental Evaluation of Flammability Parameters of Cables Using Laboratory-Scale Apparatus". Factory Mutual Research Corporation, Norwood, Mass. EPRI Project RP 1165-1; July 1979.

6. Parker, W.J., "An Assessment of Correlations Between Laboratory and Full Scale Experiments for the FAA Aircraft Fire Safety Program, Part 3: ASTM E84". Nat. Bur. Stand.(U.S.) NBSIR 82-2564; January 1983.

7. Van Volkinburg, D.R., et al, "Toward a Standard Ignition Source." Lawrence Berkeley Laboratory, University of California, Berkeley, California. Paper No. 78-64; October 1978.

8. Lee, B.T., "Effect of Ventilation on the Rates of Heat, Smoke, and Carbon Monoxide Production in a Typical Jail Cell Fire". Nat. Bur. Stand. (U.S.) NBSIR 82-2469; March 1982. 
9. Cline, D.D. and Von Riesemann, W.A., and Chavez, J.M., "Investigation of Twenty-Foot Separation Distance as a Fire Protection Method as Specifled In 10 CFR 50, Appendix R" Sandia National Laboratories, Albuquerque, N.M. NUREG/CR-3192 SAND 83-0306 RP; October 1983.

10. Fisher, F.L., Personal Communication. Lawrence Berkeley Laboratory, University of California, Berkeley, California.

11. Blackshear, P.L., and Kanury, A.M., "Some Effects of Size, Orientation, and Fuel Molecular Weight on the Burning of Fuel-Soaked Wicks". Eleventh Symposium (Internationa1) on Combustion, pp. 545-552, The Combustion Institute, Pittsburgh, PA; 1967.

12. Quintiere, J.G., and Harkeleroad, M., "New Concepts for Measuring Flame Spread Properties". Symposium on Application of Fire Sclence to Fire Engineering, ASTM STP 882, American Society of Testing and Materials, Philadelphia, PA; (1985?)

13. Chamberlain, D.L., "Heat Release Rates of Lumber and Wood Products". Behavior of Polymeric Materials in Fire, ASTM STP 816, pp 21-41, E.L. Schaffer, Ed., American Society for Testing and Materials, Philadelphia, PA; 1983.

14. Atreya, A., "Pyrolysis, Ignition and Fire Spread on Horizontal Surfaces of Wood". Doctor of Philosophy thesis in Engineering. Harvard University Cambridge, Mass.; May 1983.

15. Krasner, L., "Burning Characteristics of Wooden Pallets as a Test Fuel". Factory Mutual Research Corporation, Norwood, Mass. Progress Report Serial No. 16437; May 27, 1968.

16. Alpert, R.I. and Ward, E.J., "Evaluation of Unsprinklered Fire Hazards". Fire Safety Journa1, Vo1. 7, No. 2, pp 127-143; 1984. 
17. Modak, A.T., "Ignitability of High-Fire-Point Liquid Spil1s". Factory Mutual Research Corporation, Norwood, Mass. Final Report NP-1731, Research Project 1165-1; March 1981.

18. Babrauskas, V., "Estimating Large Pool Fire Burning Rates". Fire Technology, No1. 19, No. 4, pp 251-261; November 1983.

19. Mudan, K.S., "Thermal Radiation Hazards from Hydrocarbon Pool Fires". Progress in Energy and Combustion Science, Vol. 10, No. 1, pp 59-80; 1984. 


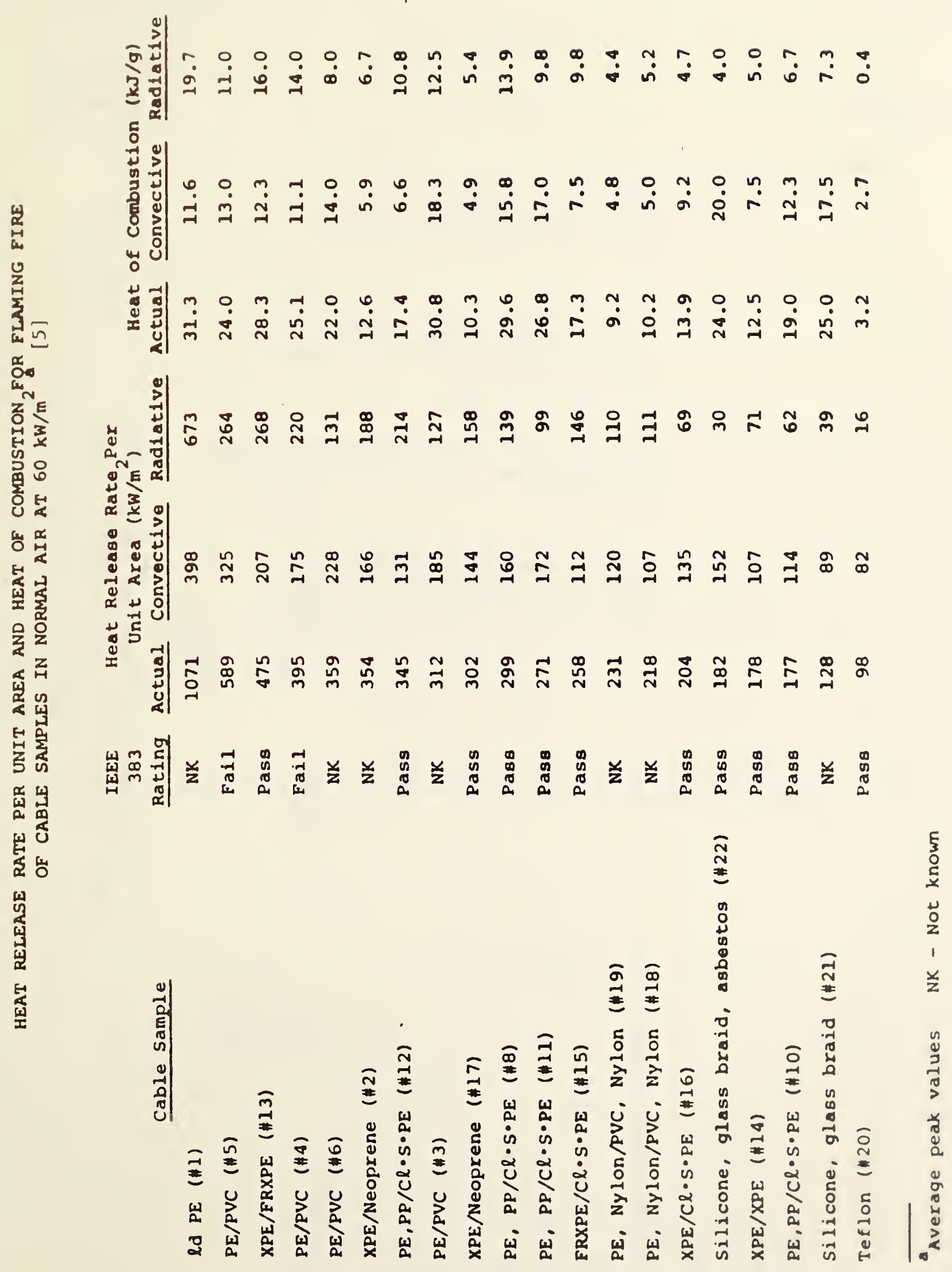


Experiment

No.
Fuel Source
Peak Heat

Release Rate

$(\mathrm{kW})$

3

$9.1 \mathrm{~kg}$ computer paper crumpled

109 up in two plastic trash bags.

4, 11

$11.4 \mathrm{~kg}$ rags, $7.7 \mathrm{~kg}$ paper towels, $5.9 \mathrm{~kg}$ plastic gloves and tape, $5.9 \mathrm{~kg}$ methyl alcohol. Contents mixed in two 40 gal trash bags.

5,10

$13.6 \mathrm{~kg}$ computer paper crumpled up and divided in two $7.5 \mathrm{~kg}$ (50 gal) plastic trash cans. and $31.8 \mathrm{~kg}$ folded computer paper. Paper evenly divided into two bags.

Table 2. Simulated Trash Fire Experiments at Sandia National Laboratories 


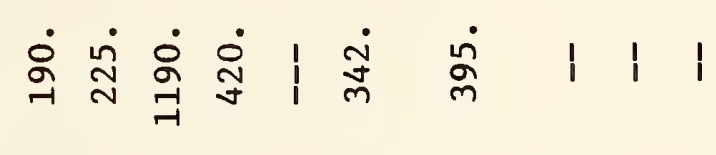

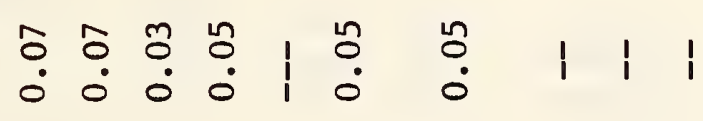

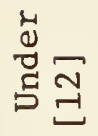

o

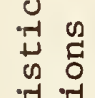

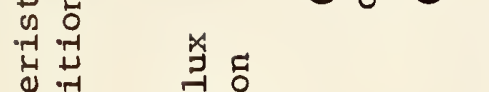

跎

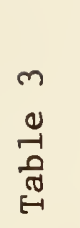

先 0

密崖

在

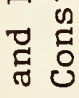

站

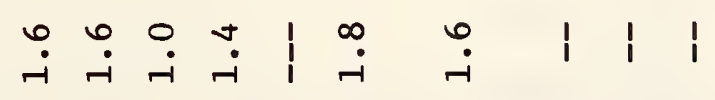

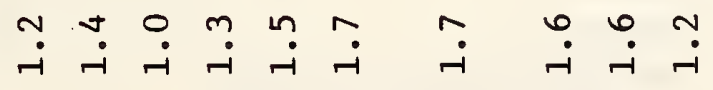

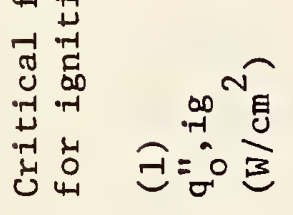

牙苟

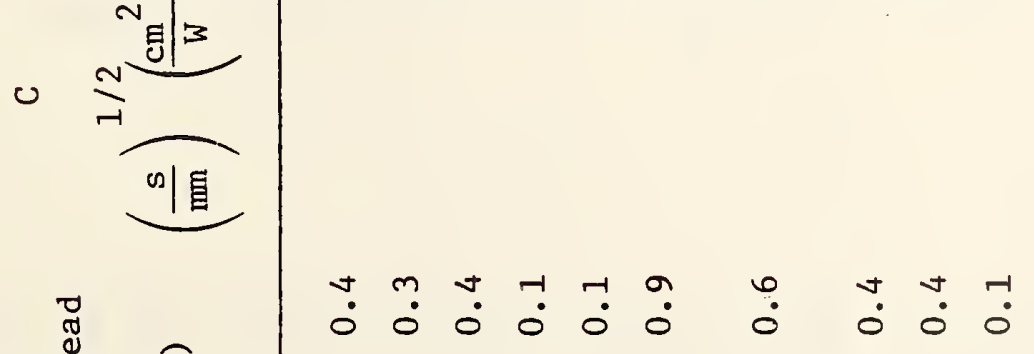

$\underset{ت}{ \pm}$

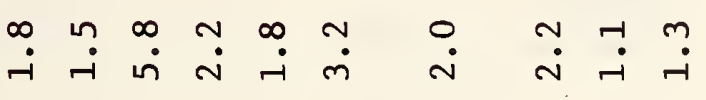




\begin{tabular}{|c|c|c|c|c|c|c|c|}
\hline \multirow[b]{2}{*}{$\begin{array}{l}\text { Mrenuls } \\
\text { Ded Norninal } \\
\text { Drmensions }\end{array}$} & \multirow[b]{2}{*}{$\begin{array}{l}\text { Number } \\
\text { of } \\
\text { Sumples }\end{array}$} & \multirow[b]{2}{*}{$\begin{array}{l}\text { Tume bo } \\
\text { lenivos. } \\
\text { ? }\end{array}$} & \multirow{2}{*}{$\begin{array}{l}\text { Tume wo } \\
\text { Pest } \\
\text { HRR, } \\
\text {. }\end{array}$} & \multicolumn{3}{|c|}{ Mean HRR. kW/m' } & \multirow[b]{2}{*}{$\begin{array}{l}\text { Ia-min Toul } \\
\text { Heal Release. } \\
\mathrm{M} / \mathrm{m}^{2}\left(\mathrm{Bw} / \mathrm{f}^{2}\right)\end{array}$} \\
\hline & & & & Pent & $\begin{array}{l}\text { Furl } \\
\text { I.min } \\
\text { Average }\end{array}$ & $\begin{array}{c}\text { Fust } \\
\text { 5-min } \\
\text { Average }\end{array}$ & \\
\hline $\begin{array}{l}\text { Sounters pix } \\
2 \text { by } 8 \text { is. lumber }\end{array}$ & $s$ & 17 & 60 & 134 & 96 & 109 & $57.7(5080)$ \\
\hline $\begin{array}{l}\text { Dougles fis } \\
2 \text { by } 8 \text { in. lumber }\end{array}$ & 3 & 14 & 40 & 124 & 89 & .79 & $43.8(3860)$ \\
\hline $\begin{array}{l}\text { Dougles fis } \\
2 \text { by } 6 \text { in. lumber }\end{array}$ & 4 & 15 & 28 & 98 & 59 & 78 & $45.3(3990)$ \\
\hline $\begin{array}{l}\text { Redwood } \\
2 \text { by } 8 \text { in. Lumber }\end{array}$ & 9 & 11 & 20 & 118 & 95 & 71 & $38.1(3350)$ \\
\hline $\begin{array}{l}\text { Dougles fir } \\
\text { thu is plywood }\end{array}$ & 2 & 12 & 17 & 115 & 90 & 70 & $38.8(3420)$ \\
\hline $\begin{array}{l}\text { Dougles fis } t_{t} \text { in. } \\
\text { ansine plywood }\end{array}$ & 3 & 8 & 19 & 119 & 98 & 82 & $43.4(3820)$ \\
\hline $\begin{array}{l}\text { Paruck baard, } \\
x \text { in. }\end{array}$ & 3 & 26 & 104 & 132 & 95 & 109 & $58.8(5180)$ \\
\hline Acoursical ive A & 5 & 10 & 62 & 96 & 68 & 61 & $\ldots \quad \ldots$ \\
\hline Acousened ile B & 5 & 9 & 41 & 100 & 83 & 65 & $\ldots \quad \ldots$ \\
\hline $\begin{array}{l}\text { Hurdbourd. } \\
\text { modum density; } \\
\text { pape -facod, } \\
V_{\infty} \text { is }\end{array}$ & 4 & 25 & 29 & 355 & 150 & 118 & $\ldots$ \\
\hline $\begin{array}{l}\text { Herdboard, } \\
\text { medwum density. } \\
k \text { in }\end{array}$ & 3 & 21 & 197 & 158 & 94 & 120 & $\cdots$ \\
\hline $\begin{array}{l}\text { Hardboand, } \\
\text { bugb deasity; } \\
\text { h: wo }\end{array}$ & 3 & 33 & 153 & 380 & 112 & $\cdots$ & $\ldots \quad \ldots$ \\
\hline
\end{tabular}

Table 4. Rate of heat release per unit area for selected wood products 


\section{Table 5}

UNCONFINED SPIIL DEPTHS FOR HYDROCARBON LIQUIDS

ON EPOXY-COATED CONCRETE AND STEEL [17]

Liquid

- 2 Fuel oil

"6 Residual oil

MObil DTE 797

Pennzoil 30-1ED

Fyrquel 220
Spill Depth (man)

0.22

NA

0.34

0.75

0.84 
Table 6 Data for Large Pool Buming Rate Estimates

[18]

\begin{tabular}{|c|c|c|c|c|c|c|c|c|}
\hline Meterial & $\begin{array}{l}\text { Density } \\
\text { agton } 1\end{array}$ & $\Delta h_{1}$ & $\begin{array}{c}\Delta h_{1} \\
\text { anJ/ngl }\end{array}$ & in: & $\begin{array}{c}k B \\
\left(m^{-1}\right)\end{array}$ & $\stackrel{8}{\left(m^{-1}\right)}$ & $\begin{array}{l}T_{1} \\
(\mathbf{K})\end{array}$ & References \\
\hline $\begin{array}{l}\text { Drosenics } \\
\text { Liquid H, } \\
\left.\text { LNG (mostly } \mathrm{CH}_{4}\right) \\
\left.\text { LPG (mostly } \mathrm{C}_{2} \mathrm{H}_{2}\right)\end{array}$ & $\begin{array}{l}700 \\
415 \\
885\end{array}$ & $\begin{array}{l}442 \\
619 \\
426\end{array}$ & $\begin{array}{r}120.0 \\
50.0 \\
46.0 \\
-\quad\end{array}$ & $\begin{array}{l}0.169( \pm 0.006) \\
0.078( \pm 0.018) \\
0.099( \pm 0.009)\end{array}$ & $\begin{array}{l}6.1( \pm 0.4) \\
1.1( \pm 0.8) \\
1.4( \pm 0.5)\end{array}$ & $\begin{array}{l}\overline{0.5} \\
0.4\end{array}$ & $\begin{array}{l}1600 \\
1500 \\
-\end{array}$ & $\begin{array}{l}4.5 \\
1.4 .30 \\
20.35\end{array}$ \\
\hline $\begin{array}{l}\text { Alcohols } \\
\text { Methenol }(\mathrm{CH}, \mathrm{OH}) \\
\text { Etheool }\left(\mathrm{C}_{3} \mathrm{H}, \mathrm{OH}\right)\end{array}$ & $\begin{array}{l}796 \\
794\end{array}$ & $\begin{array}{l}1230 \\
1000\end{array}$ & $\begin{array}{l}20.0 \\
26.8\end{array}$ & $\begin{array}{l}0.017( \pm 0.001) \\
0.016( \pm 0.001)\end{array}$ & : & $\overline{0.4}$ & $\begin{array}{l}1900 \\
1490\end{array}$ & $\begin{array}{l}5.22 .37 \\
7.9 .24 .31\end{array}$ \\
\hline 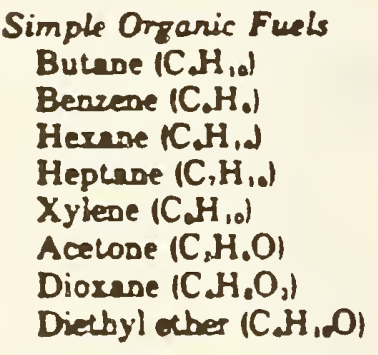 & $\begin{array}{r}679 \\
874 \\
650 \\
675 \\
870 \\
791 \\
1035 \\
\quad 714\end{array}$ & $\begin{array}{l}370 \\
500 \\
450 \\
605 \\
655 \\
670 \\
630 \\
385\end{array}$ & $\begin{array}{l}45.7 \\
40.1 \\
44.7 \\
44.6 \\
40.8 \\
25.8 \\
26.2 \\
34.2\end{array}$ & $\begin{array}{l}0.078( \pm 0.003) \\
0.085( \pm 0.002) \\
0.074( \pm 0.005) \\
0.101( \pm 0.009) \\
0.090( \pm 0.007) \\
0.011( \pm 0.003) \\
0.018^{\circ} \\
0.085( \pm 0.018)\end{array}$ & $\begin{array}{l}2.7( \pm 0.3) \\
2.7( \pm 0.3) \\
1.9( \pm 0.4) \\
1.1( \pm 0.3) \\
1.4( \pm 0.3) \\
1.9( \pm 0.3) \\
5.4^{\circ} \\
0.7( \pm 0.3)\end{array}$ & $\begin{array}{l}\overline{4.0} \\
\overline{-} \\
\overline{0} \\
\overline{0} \\
-\end{array}$ & $\begin{array}{l}1460 \\
1300 \\
- \\
- \\
= \\
-\end{array}$ & $\begin{array}{l}5 \\
5,31.38 \\
5.38,39 \\
22.33 \\
5 \\
9.29 .37 \\
33 \\
3\end{array}$ \\
\hline $\begin{array}{l}\text { Petroleum Products } \\
\text { Benzipe } \\
\text { Gasoline } \\
\text { Kerosebe } \\
\text { JP-4 } \\
\text { JP.5 } \\
\text { Transformer oil. } \\
\text { bydracarbon } \\
\text { Fuel oil, basy } \\
\text { Crude oil }\end{array}$ & $\begin{array}{c}760 \\
940-1000 \\
830-880\end{array}$ & $\begin{array}{c}- \\
330 \\
670 \\
- \\
700\end{array}$ & $\begin{array}{l}44.7 \\
43.7 \\
43.2 \\
43.5 \\
43.0\end{array}$ & $\begin{array}{l}0.048( \pm 0.002) \\
0.055( \pm 0.002) \\
0.039( \pm 0.003) \\
0.051( \pm 0.002) \\
0.054( \pm 0.002)\end{array}$ & $\begin{array}{l}3.6( \pm 0.4) \\
2.1( \pm 0.3) \\
3.5( \pm 0.8) \\
3.6( \pm 0.1 r \\
1.6( \pm 0.3)\end{array}$ & $\begin{array}{l}\overline{2.0} \\
2.6 \\
\overline{0.5}\end{array}$ & $\begin{array}{l}-\overline{1450} \\
1480 \\
1220 \\
1250\end{array}$ & $\begin{array}{l}3 \\
3,18,24,31,3 \\
3.21 \\
3,16,21,34 \\
8,14,15,32\end{array}$ \\
\hline $\begin{array}{l}\text { Solids } \\
\text { Polymethyl. } \\
\text { methacryince }\end{array}$ & 1184 & 1611 & 24.9 & $0.020( \pm 0.002)$ & $3.3( \pm 0.8)$ & 1.3 & 1260 & 12.26 \\
\hline
\end{tabular}

- Value independent of diameter in turbulant regime

- Only two dals pointo avilable 


$\begin{array}{ccc} & \% \\ \text { Hydrocarbon } & \text { Pool size } & \text { Radiative output/ } \\ \text { Combustion output }\end{array}$

Methanol

LNG on land

11

11

II

LNG on water

LPG on 1 and

Butane

Gasoline

Gasoline

Benzene

Hexane

Ethylene (m)

1.22

18.0

$0.4-3.05$

$1.8-6.1$

20.0

8.5-15.0

20.0

$0.3-0.76$

$1.22-3.05$

1. 0-10.0

1.22

--

$--$
17.0

16.4

$15.0-34.0$

20.0-25.0

36.0

12. 0-31.0*

7.0

19.9-26.9

40.0-13.0*

60.1-10.0*

$36.0-38.0$

40

38

*In these cases, the smaller diameter fires were associated with higher radiative outputs. 


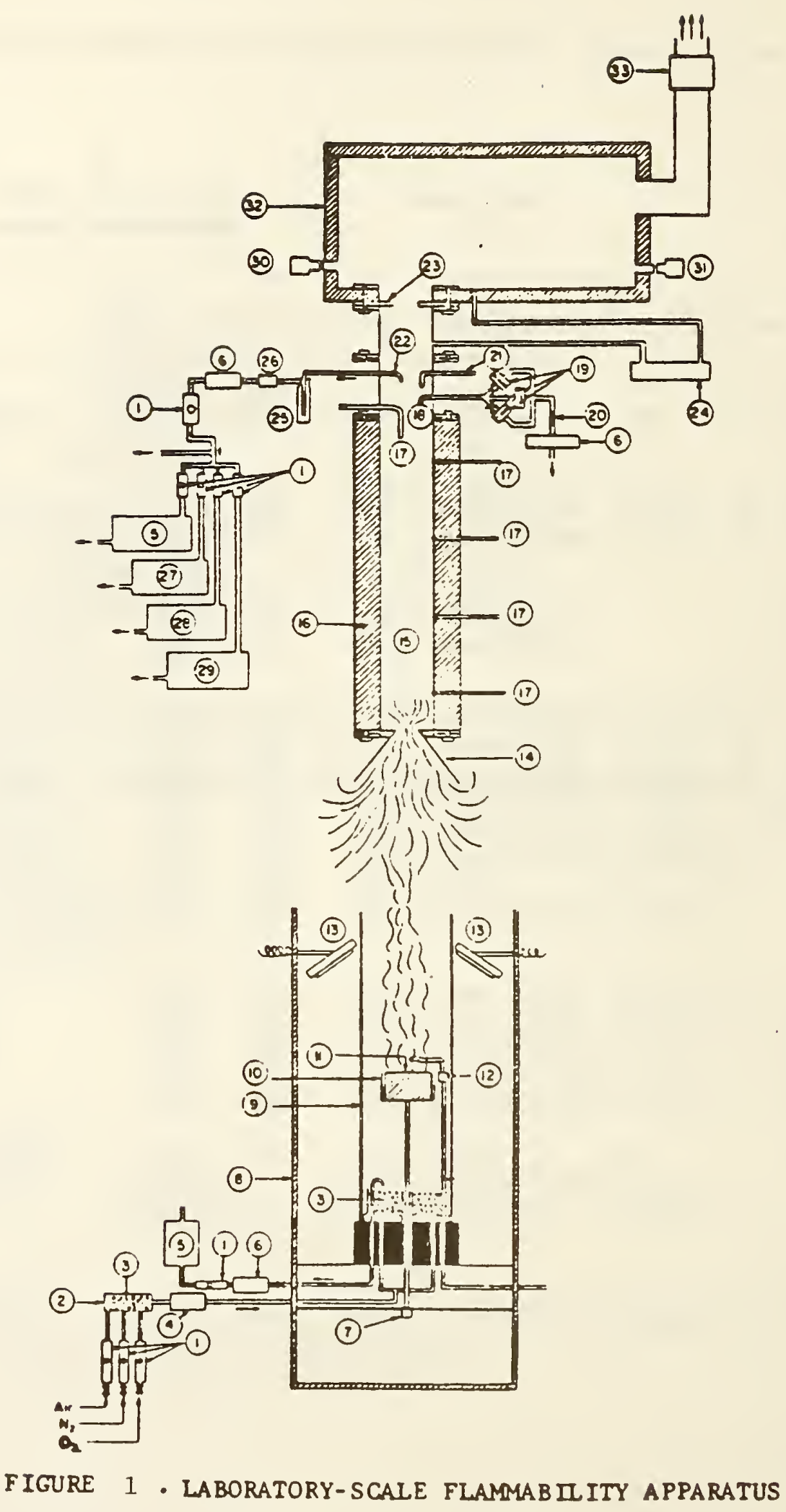




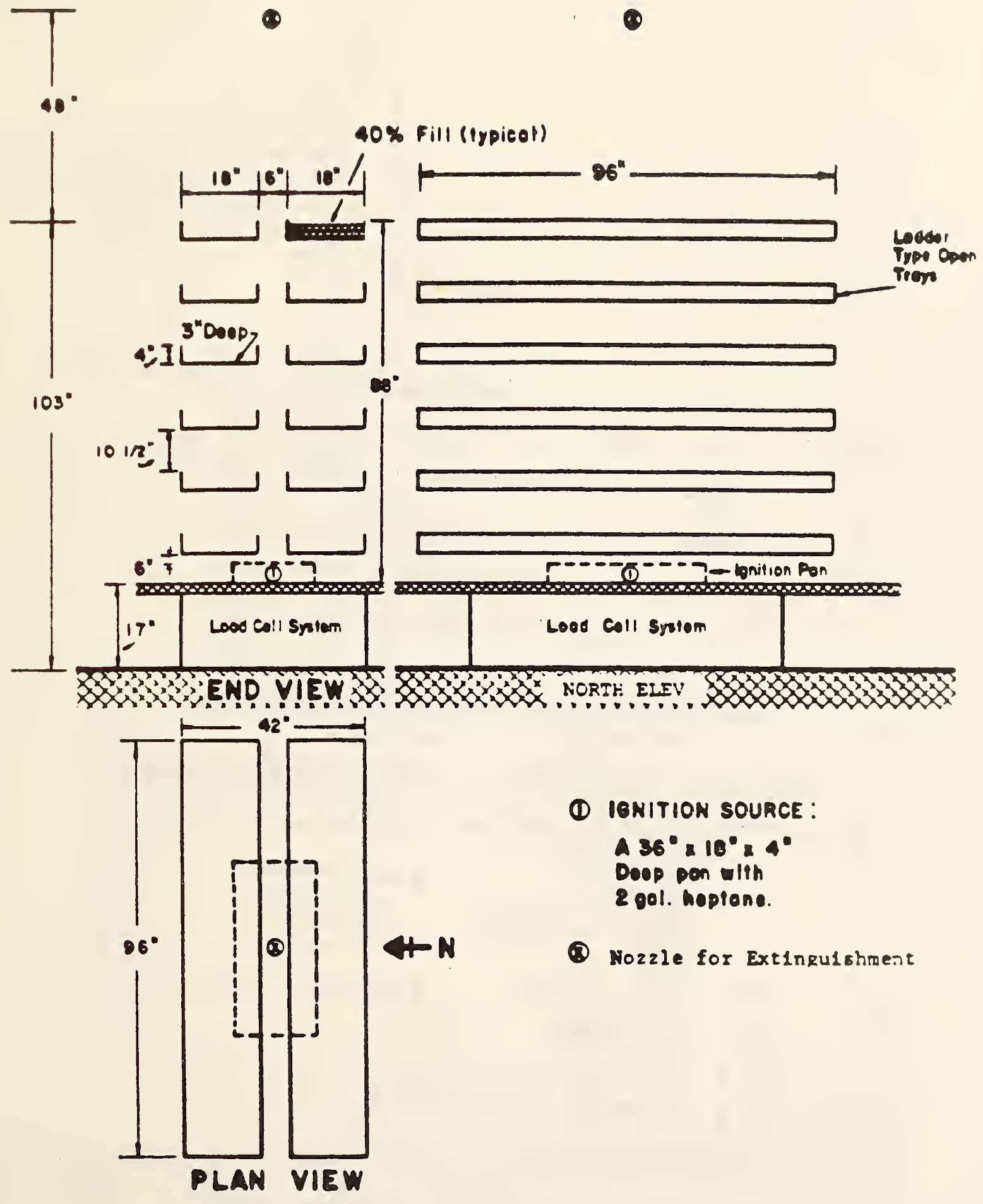

Figure 2 . Horizontal Tray Test Setup [4] 


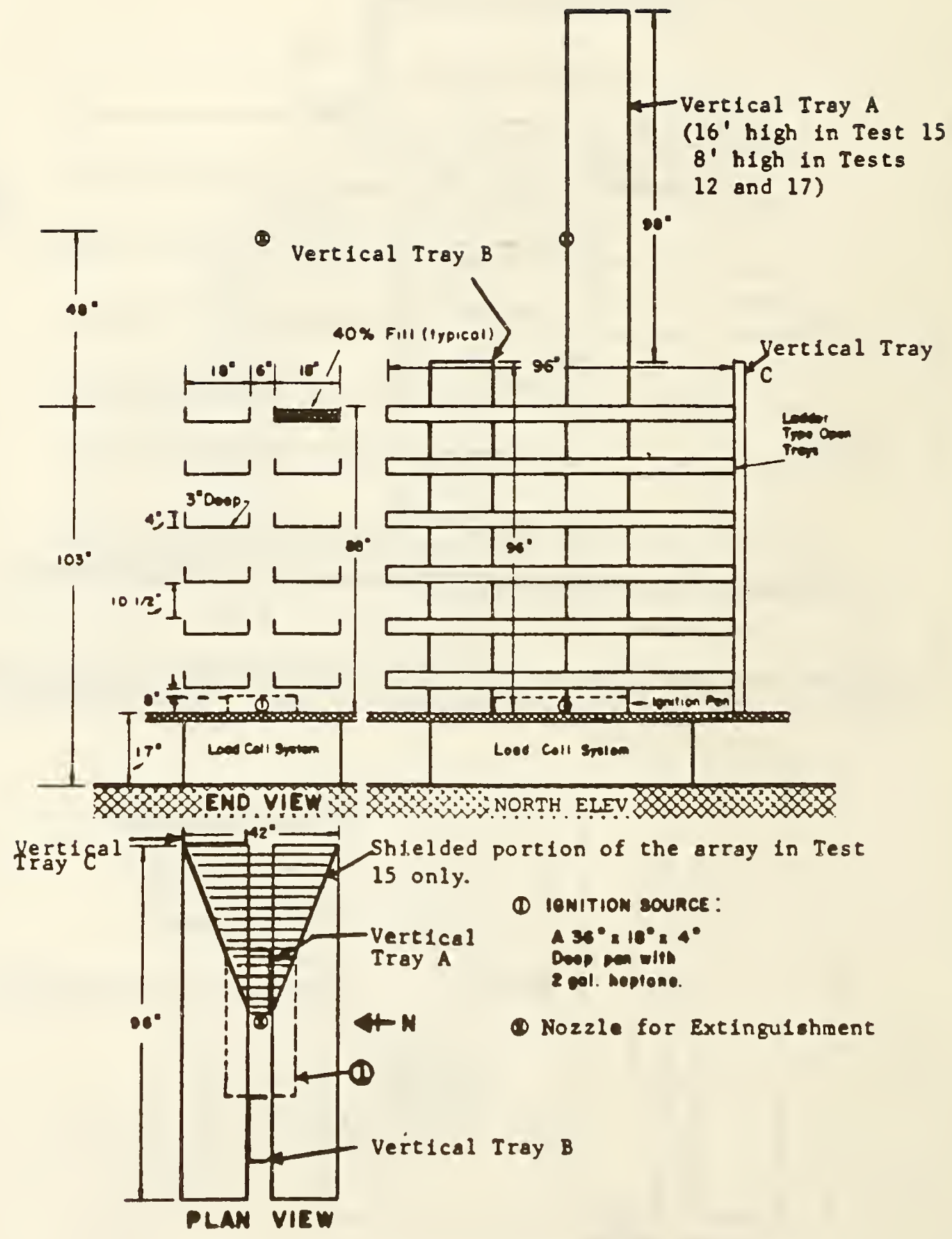

Figure 3 Mixed Tray Test Setup [4] 


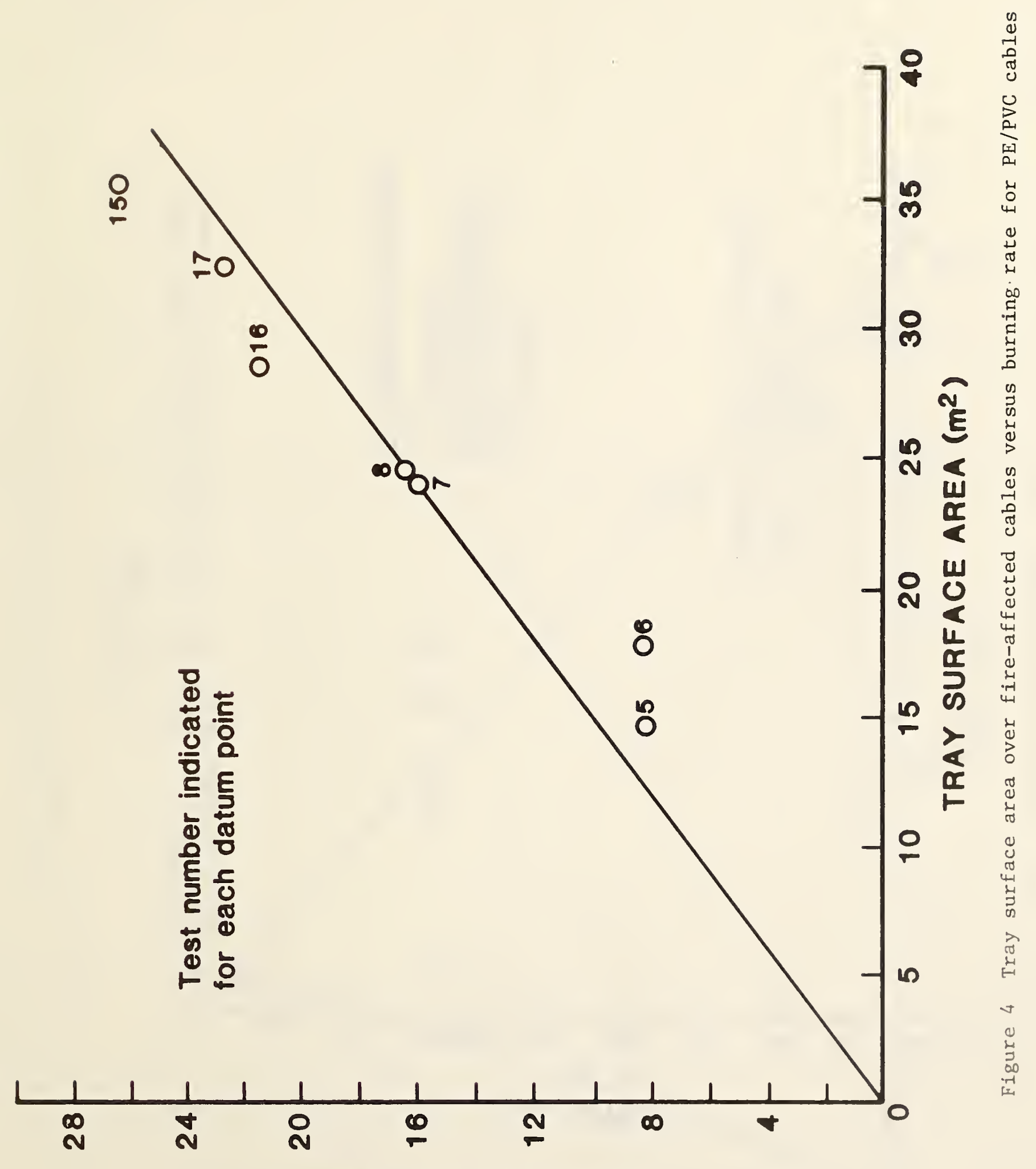

(u!w!'6x) $\exists \perp \vee y$ DNIN\&กG 


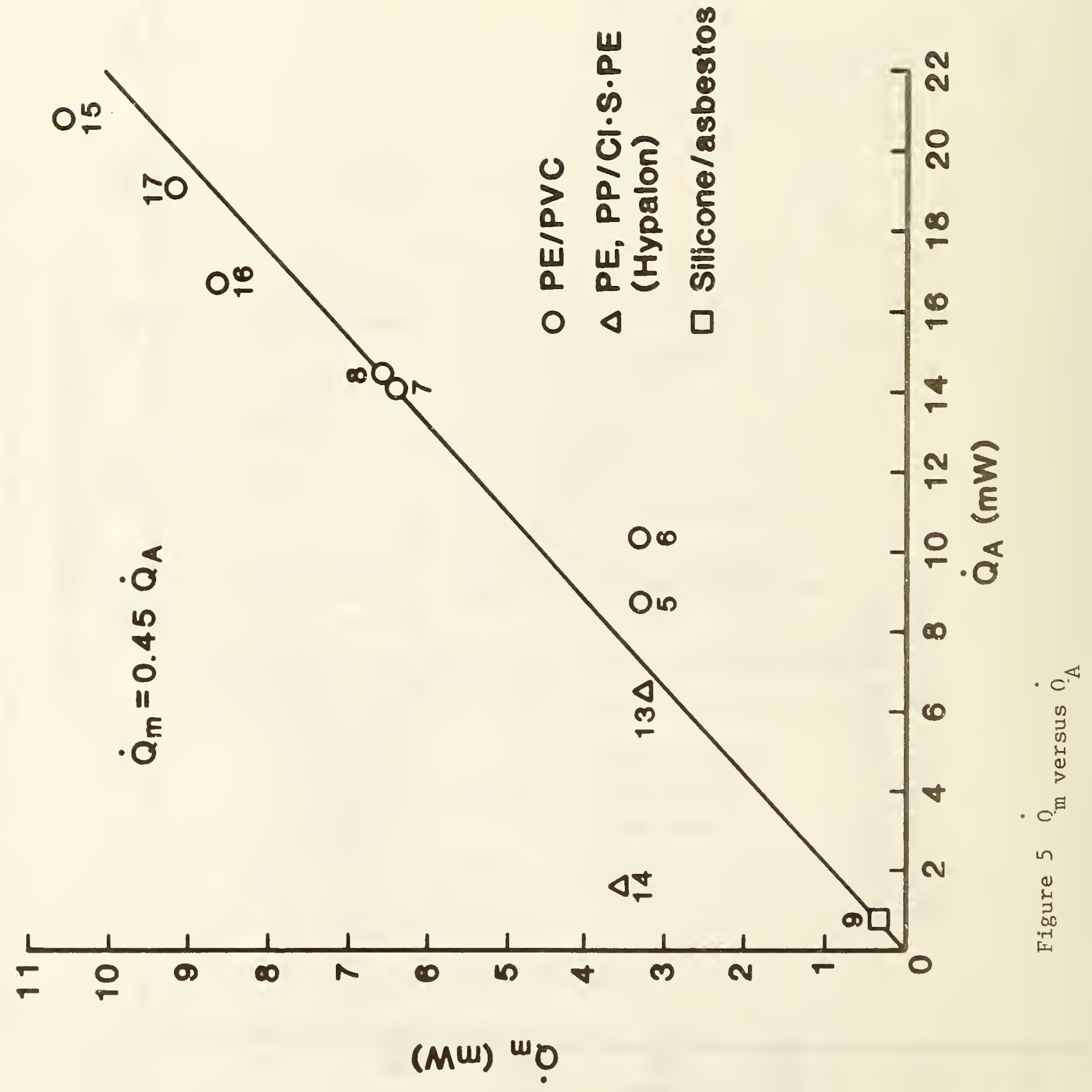




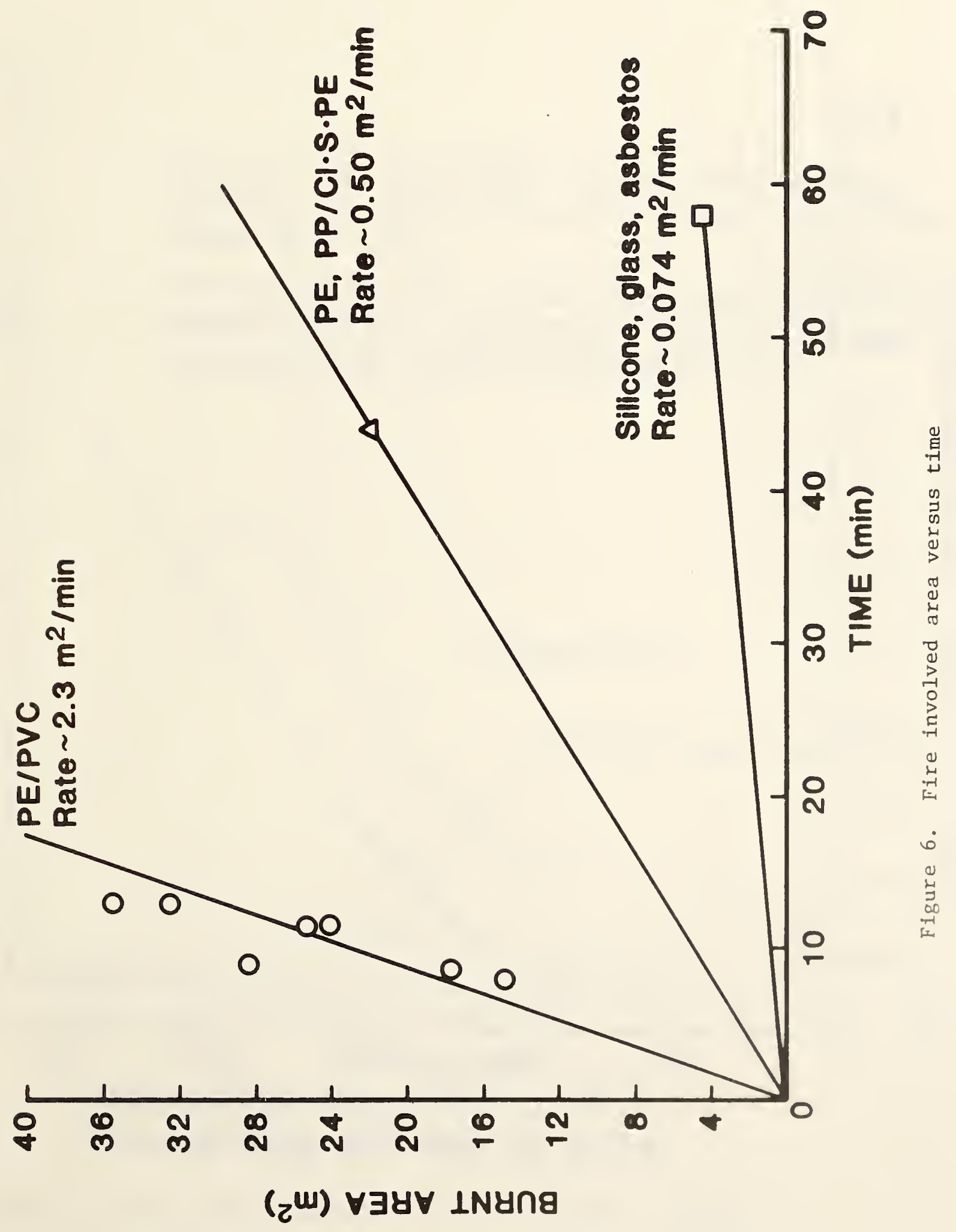




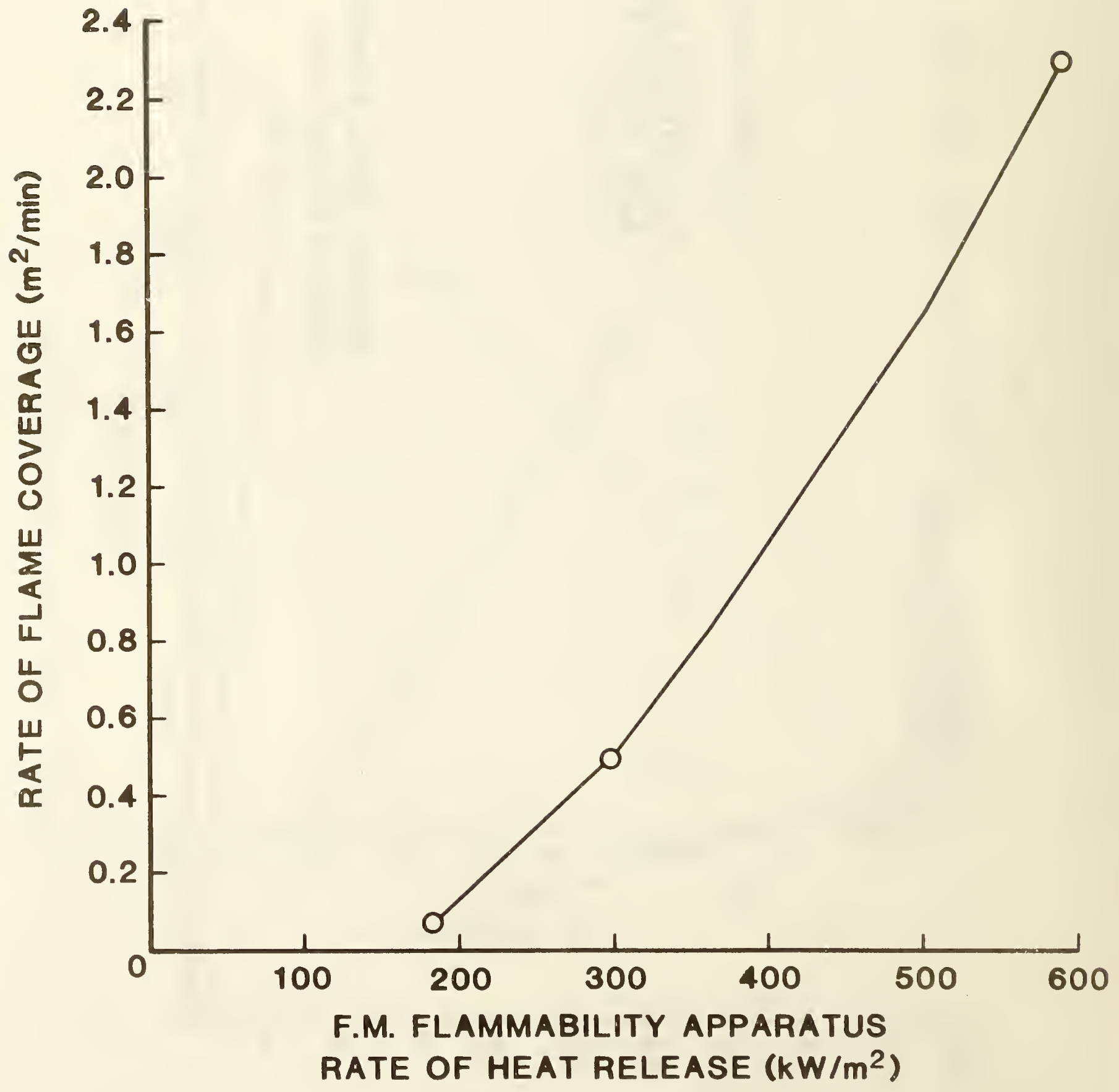

Figure 7. Rate of fire coverage versus rate of heat release 


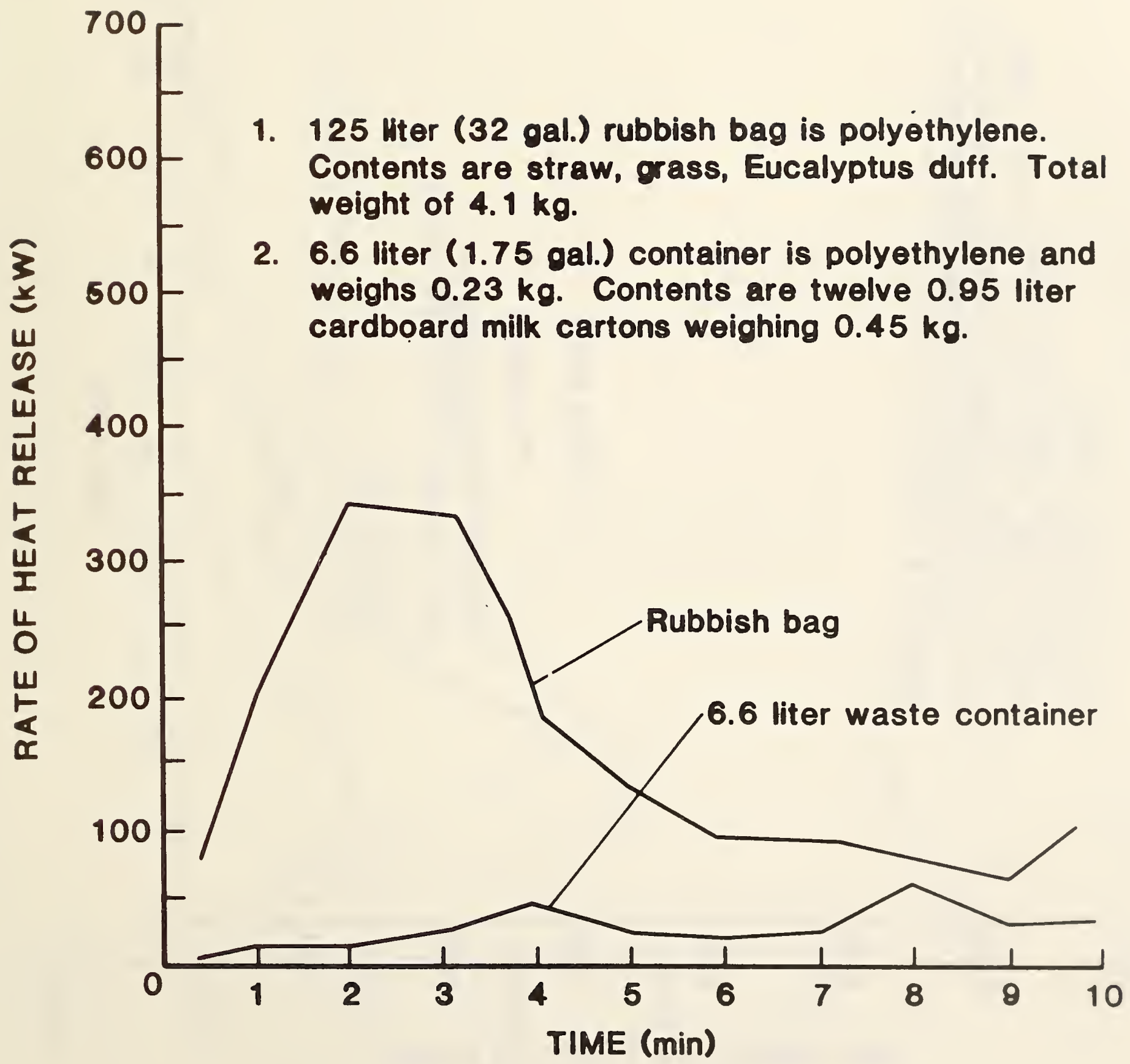

Figure 8. Trash fires [7] 


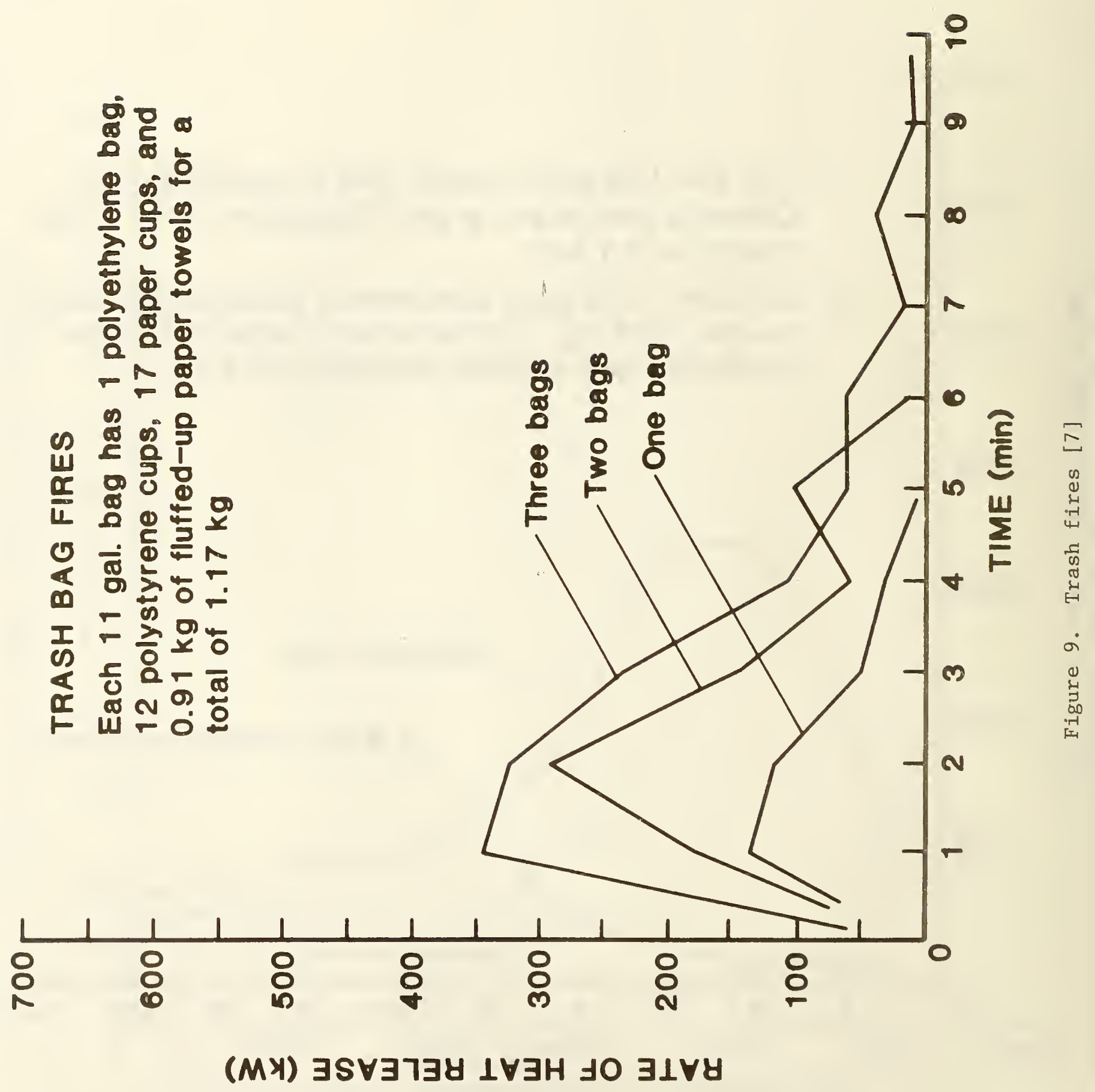




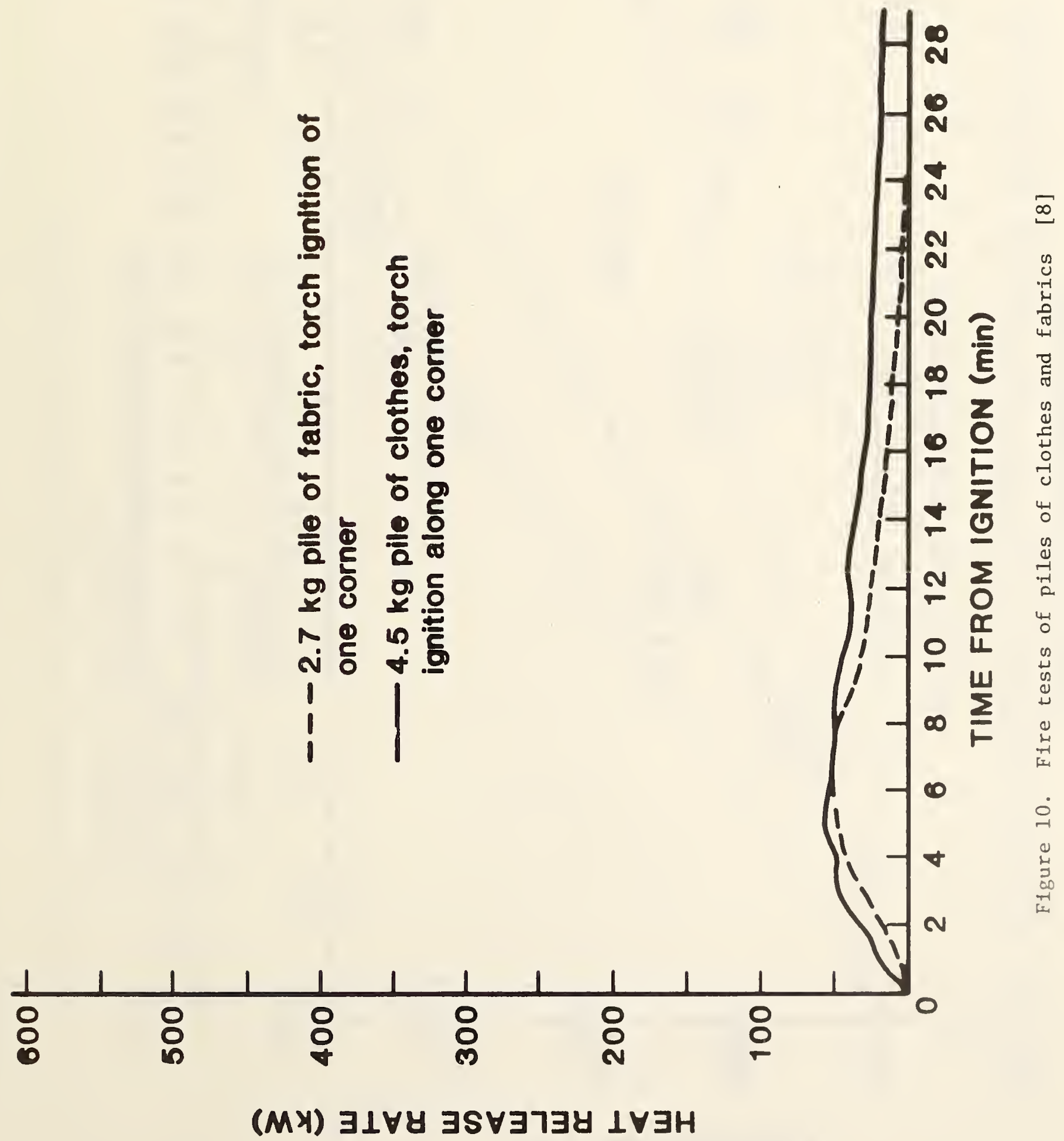




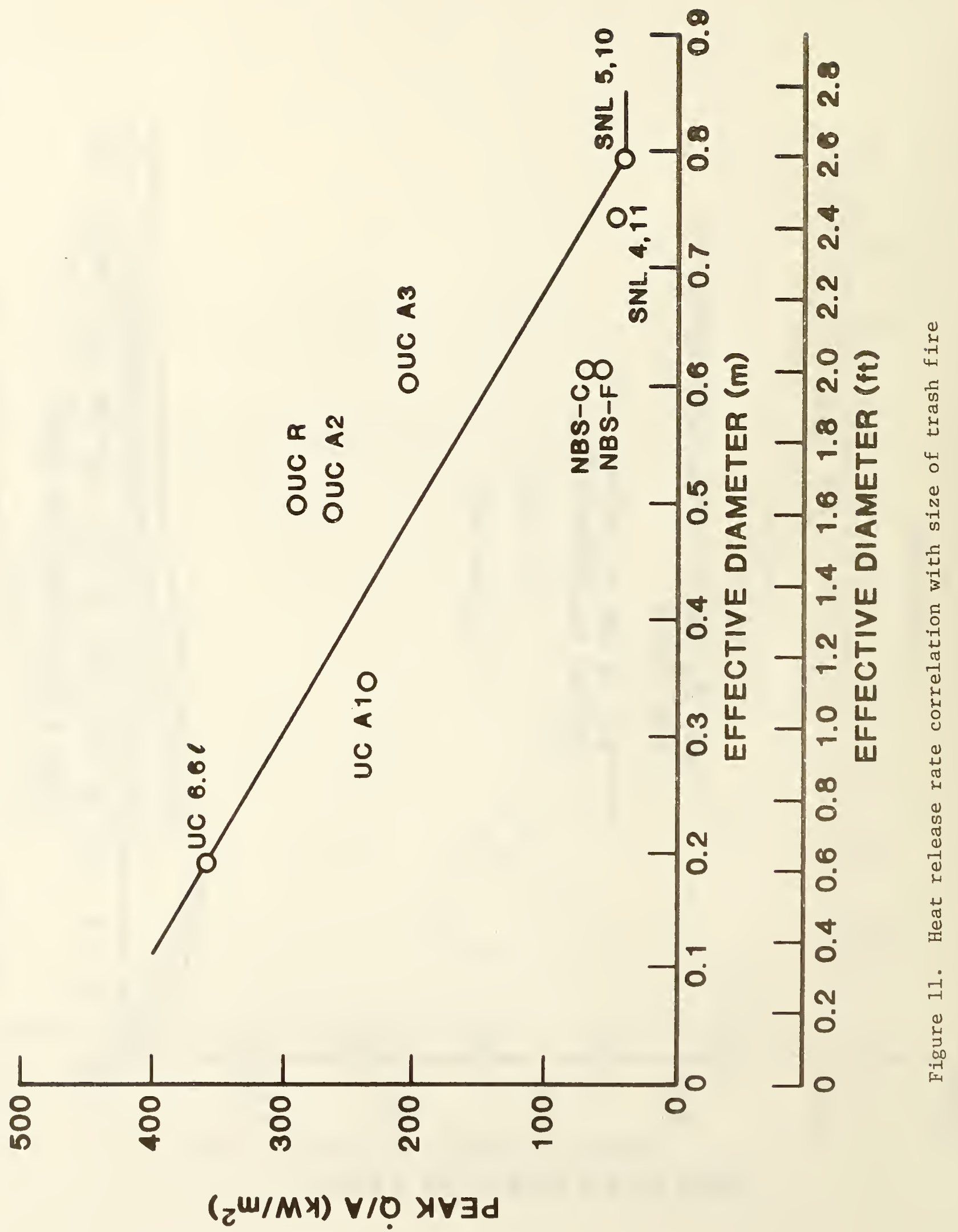




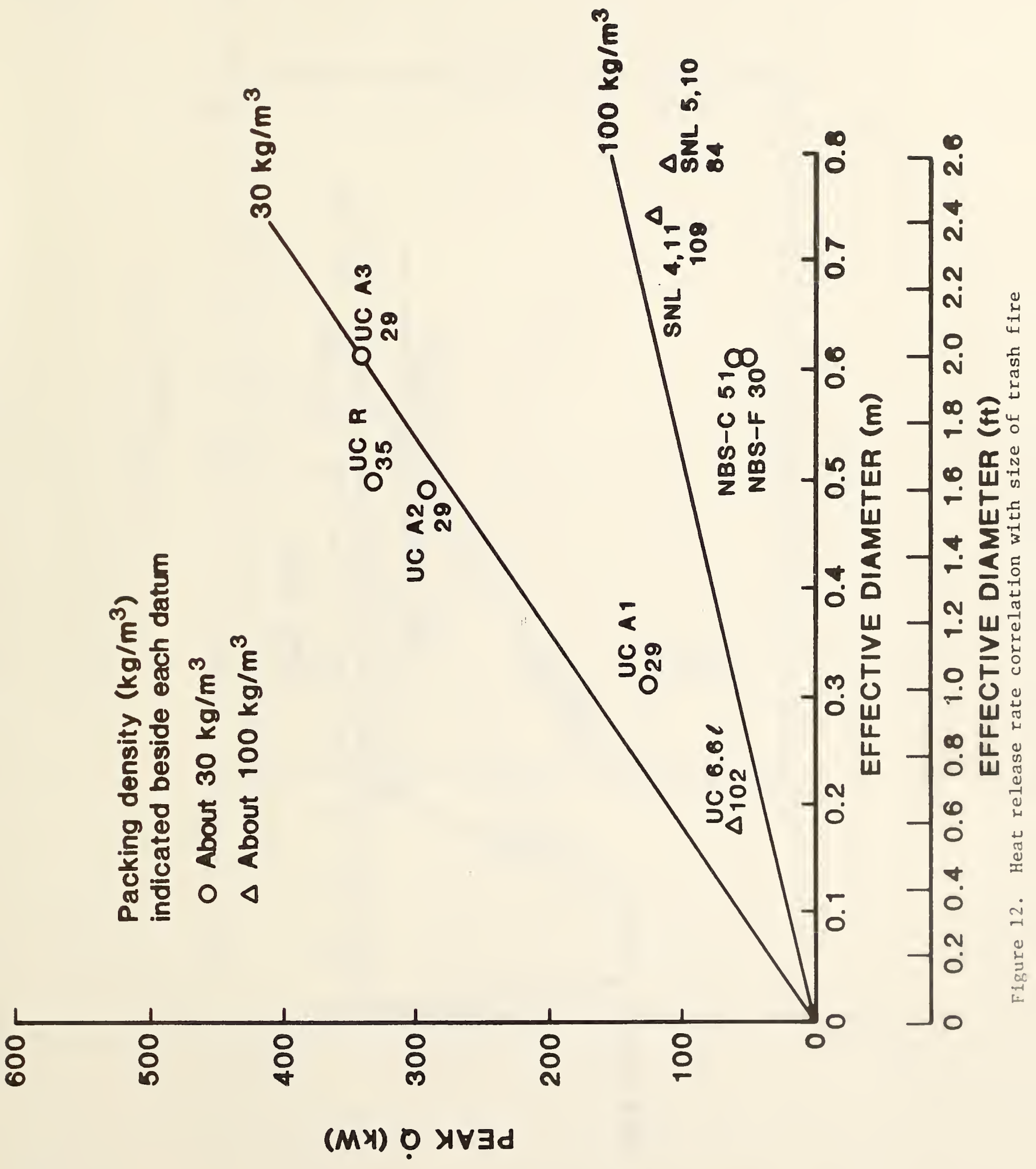




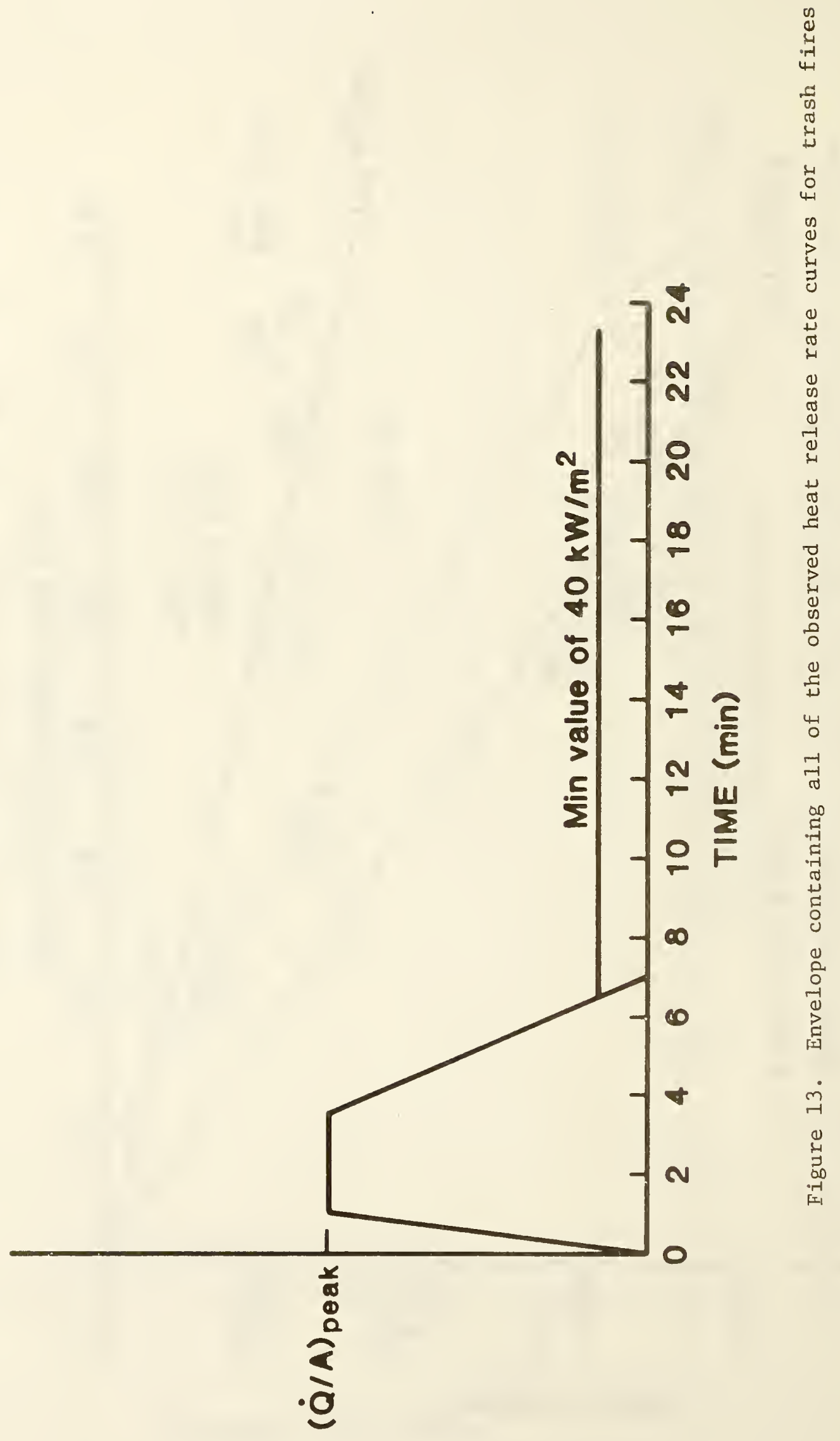

$(\vee / 0) \exists S \vee \exists า \exists y \perp \vee \exists H\lrcorner 0 \quad \exists \perp \vee y$ 


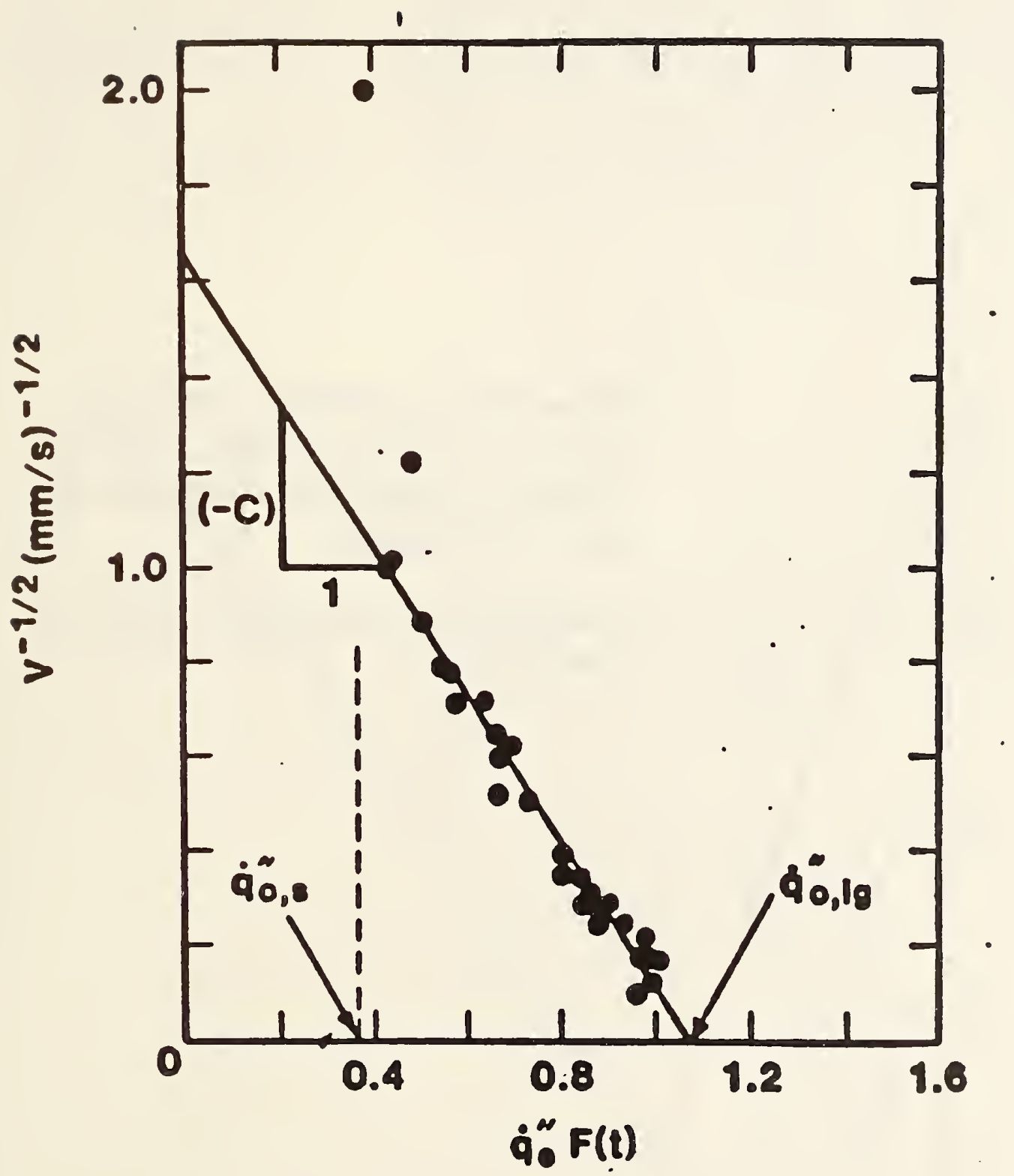

Figure 14. Correlation of velocity with flux 


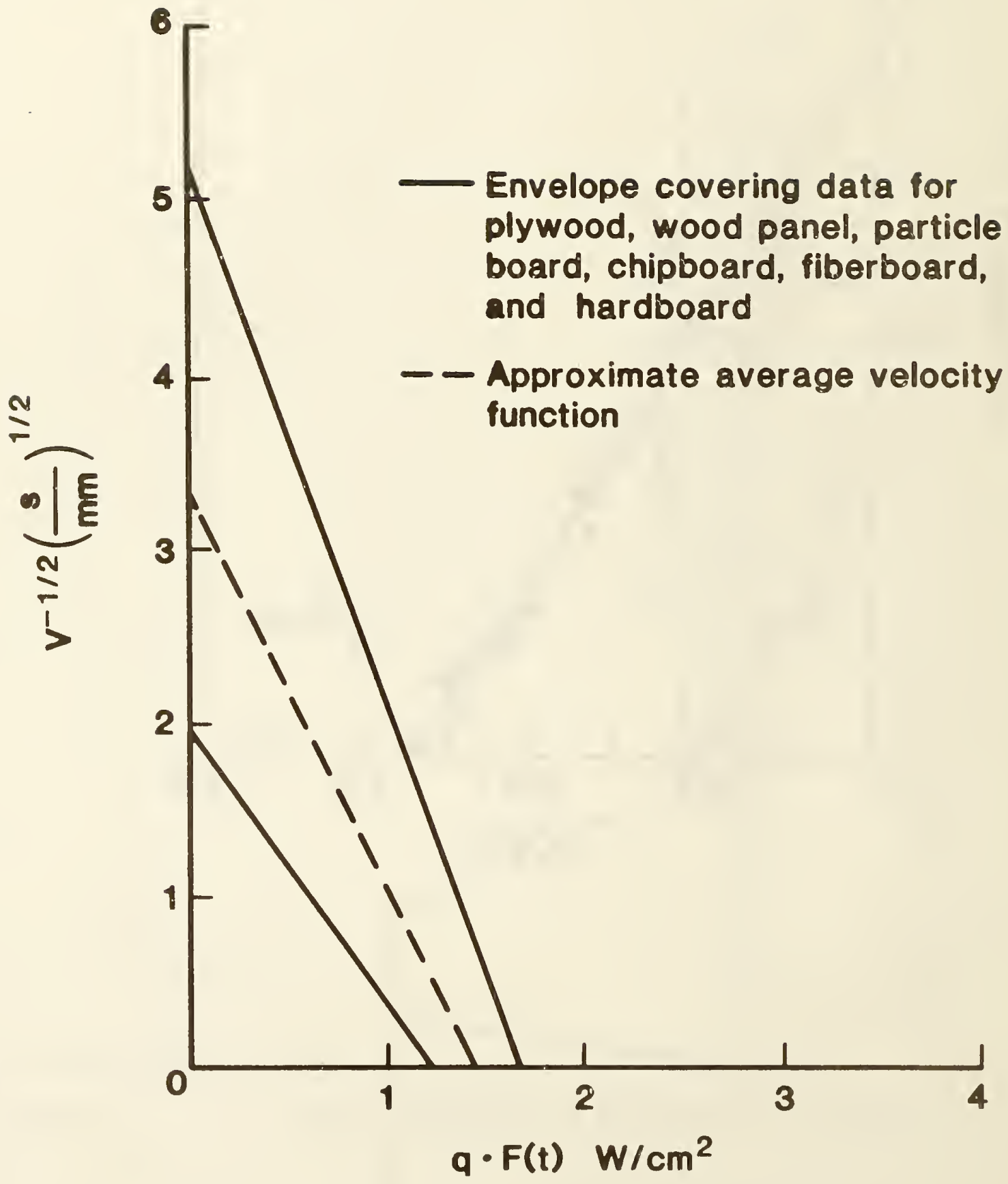

Figure 15. Envelope containing velocity versus flux data for wood products [12] 


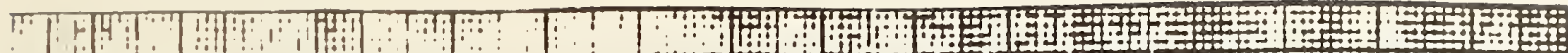
if - 1 1)

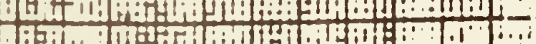

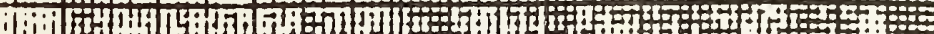
-15

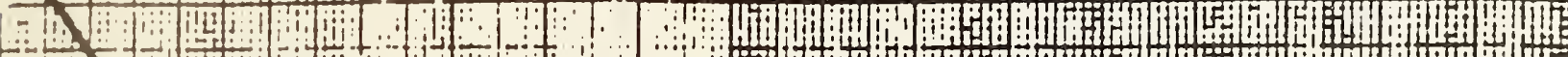

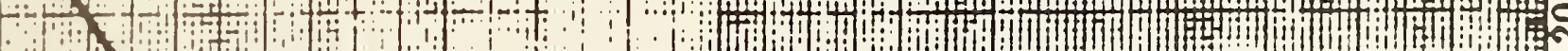

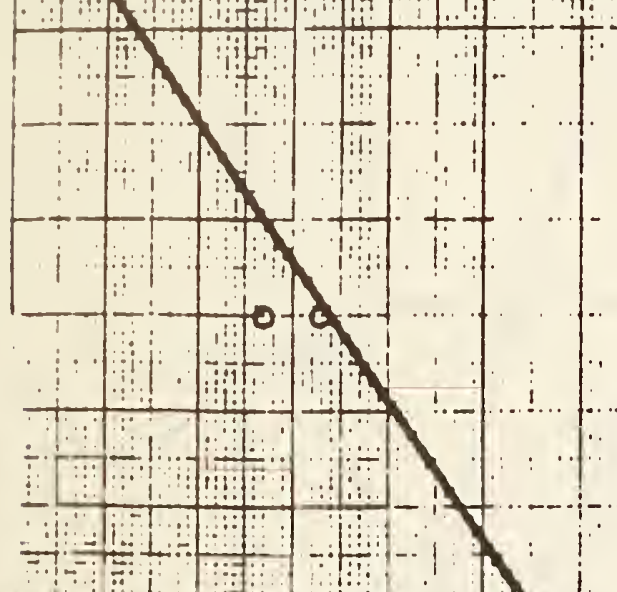

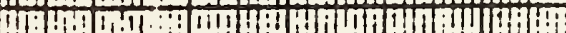
(1) 1

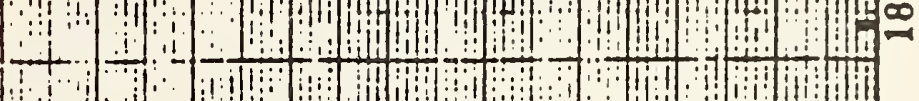
a $-1,0$ a

-

놀

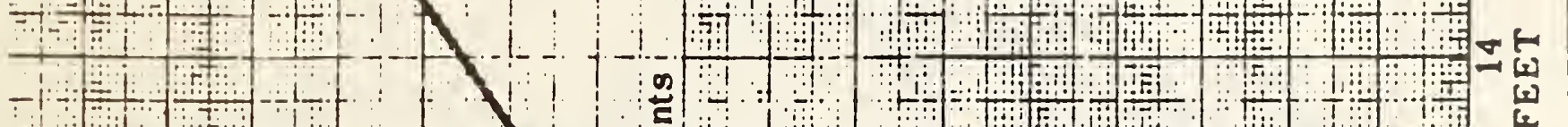
- 1 -

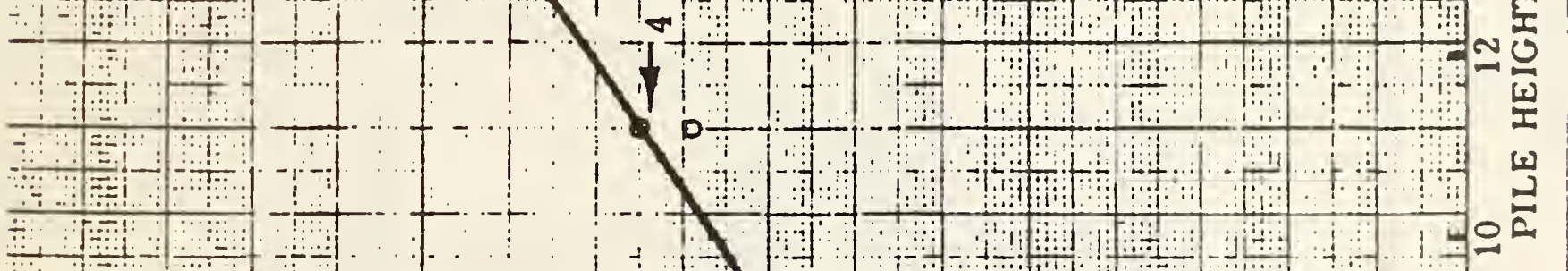
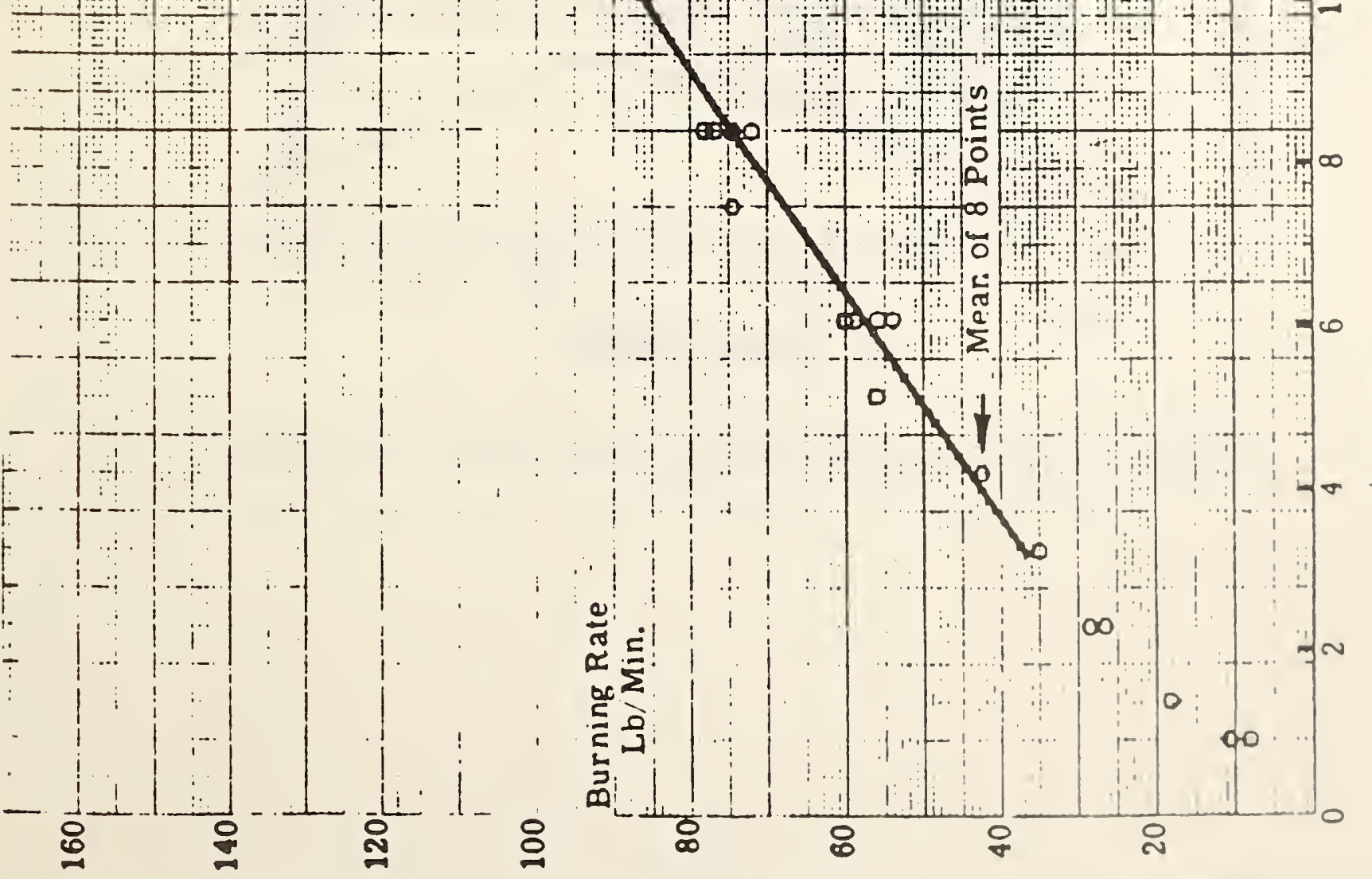


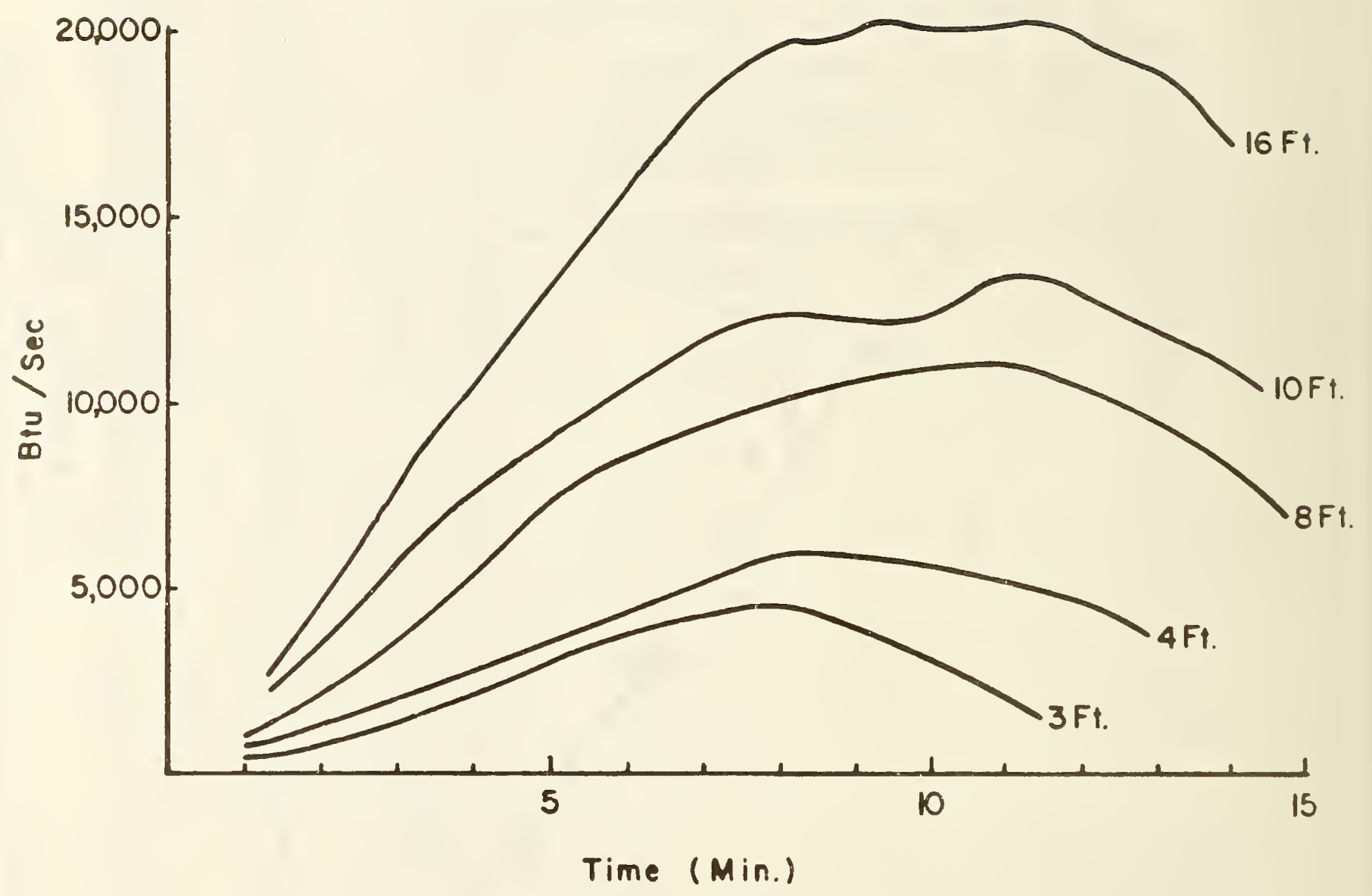

Figure 17. Heat release rate for single stacks of wood pallets [16] 


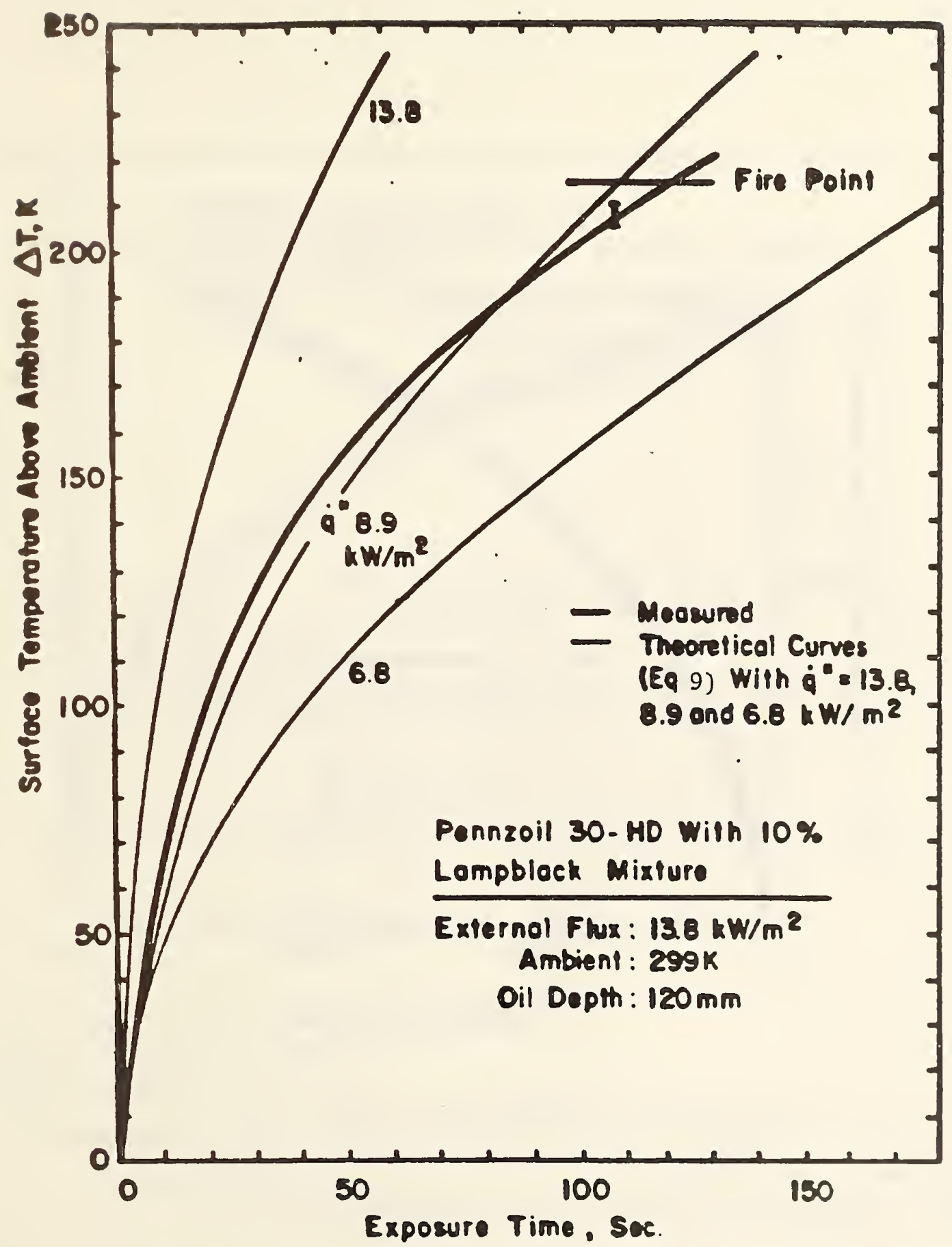

Figure 18. Measured surface temperature of an opaque, semi-infinite medium compared with theory using three different values of net flux of $13.8,8.9$ and $6.8 \mathrm{k} ! \mathrm{v} / \mathrm{m}^{2}$ and an external flux of $13.8 \mathrm{kiv} / \mathrm{m}^{2}$. 


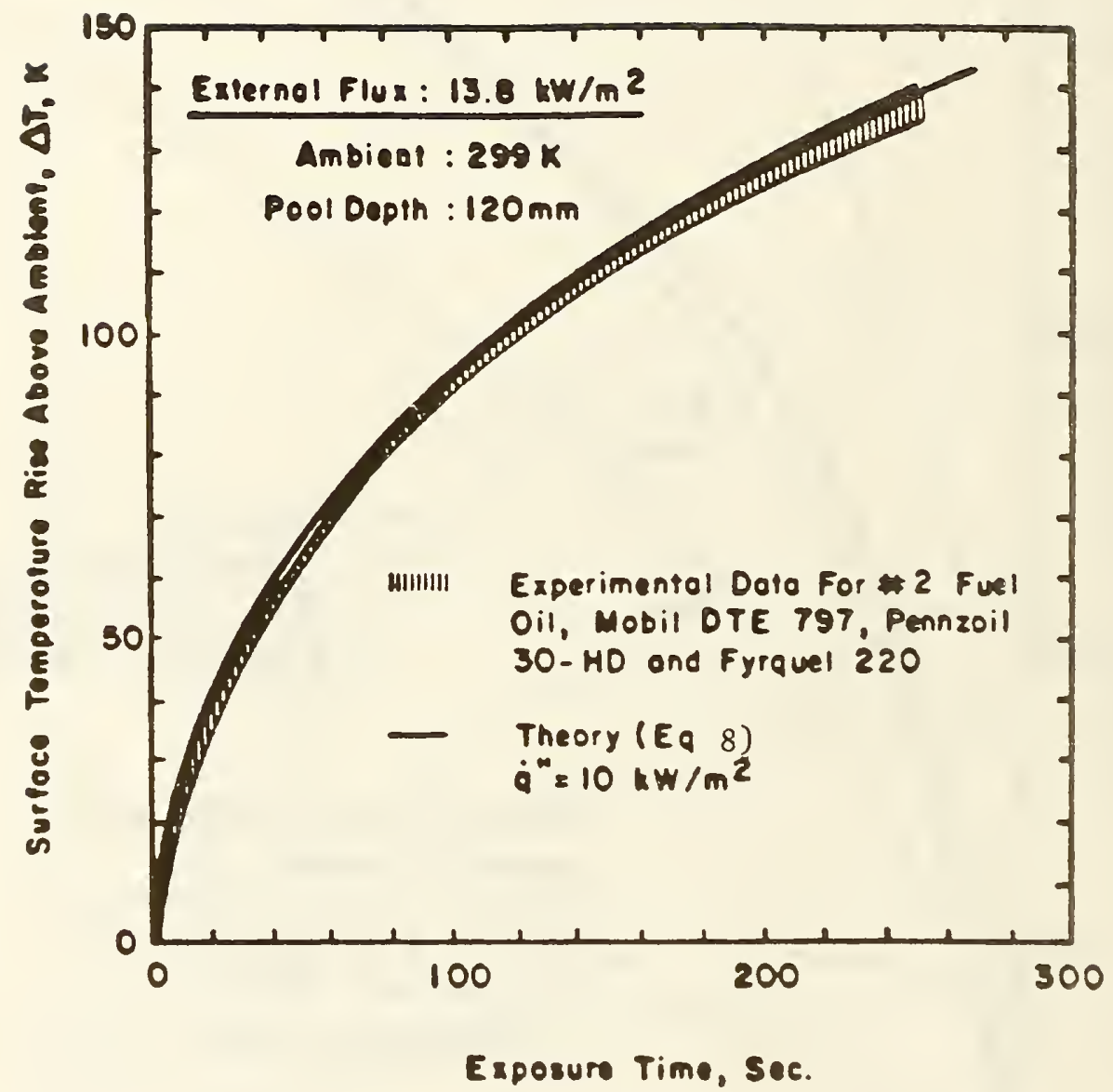

Figure 19. Measured surface temperatures (shaded region) of four semitransparent, semi-intinite hydrocarbon liquids compared with theory using a net flux of $10 \mathrm{~kW} / \mathrm{m}^{2}$ and an external flux of $13.8 \mathrm{kN} / \mathrm{m}^{2}$. 


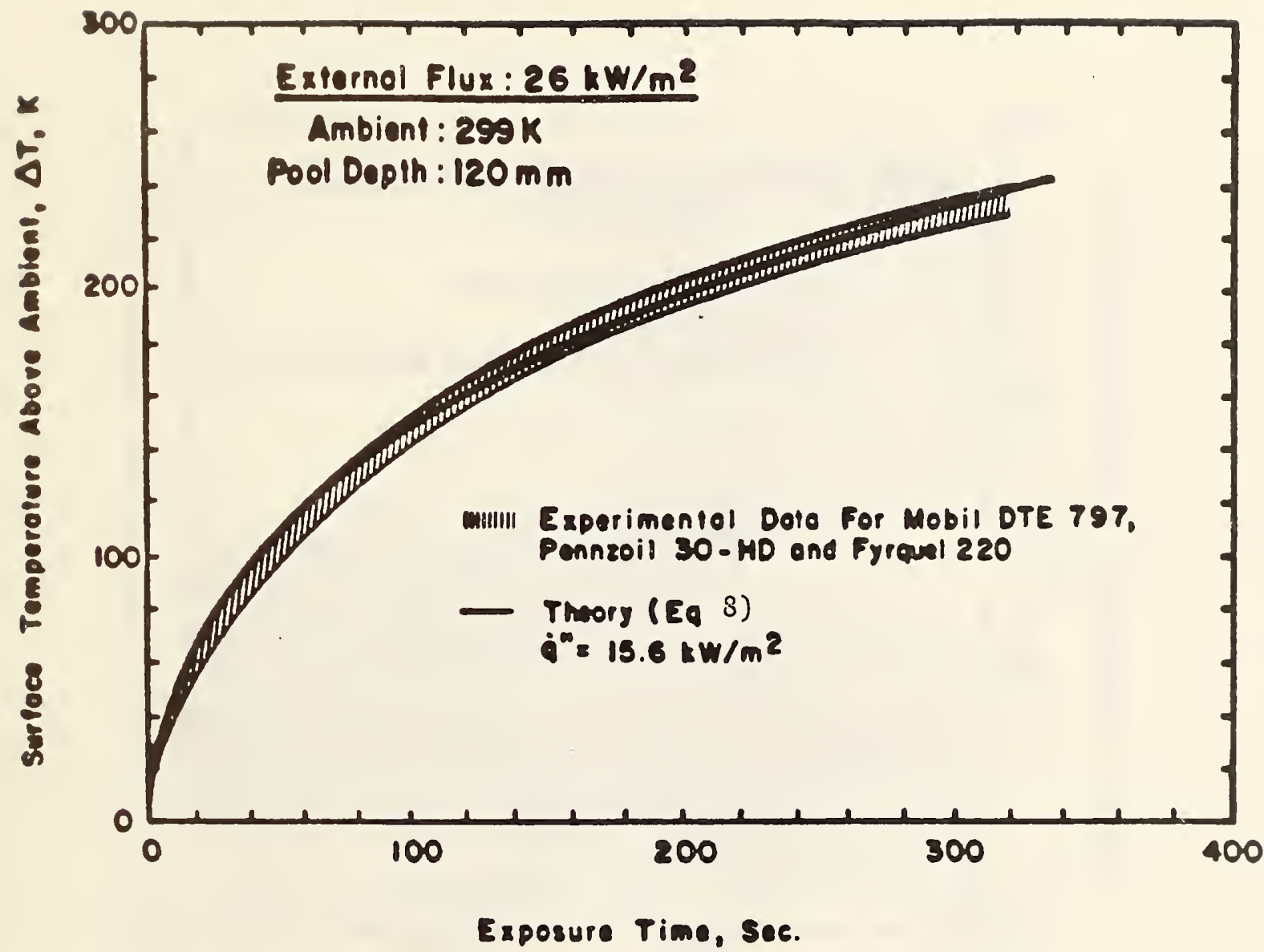

Figure 20. Comparison of theory and experiment for net flux of $15.6 \mathrm{~kW} / \mathrm{m}^{2}$ and an external fiux of $26 \mathrm{~kW} / \mathrm{m}^{2}$. 


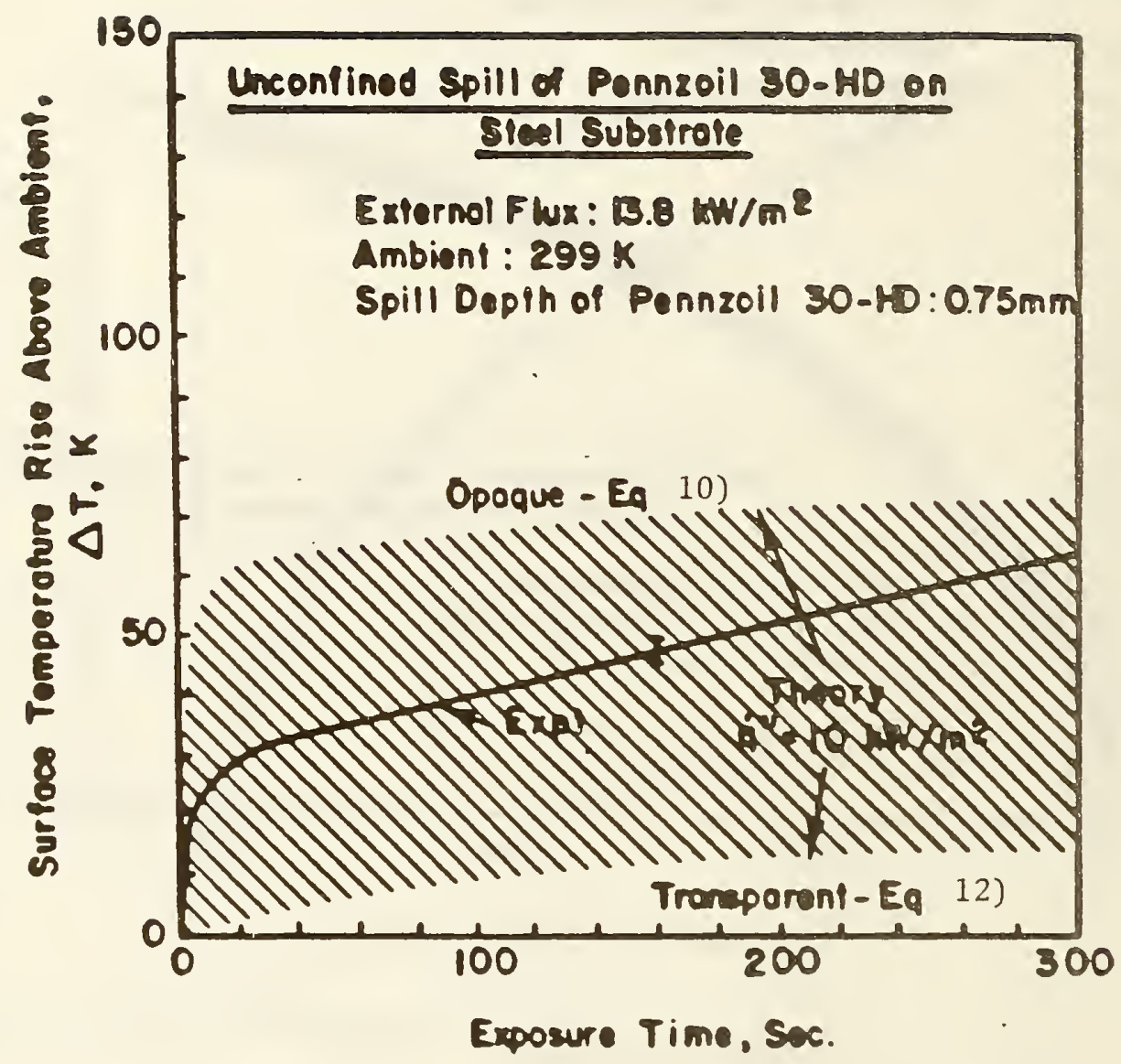

Figure 21. Comparison of experiment and the range predicted by two theoretical limits for an unconfinec spill of Pennzoil 30-HD on a steel substrate. 




Figure 22. Doconfined sp111 of Pennzo11 30-BD on an epoxy-coated concrete substrate. 
NCS-114) (REV. $2-80$ )

U.S. DEPT. OF COMM.

BIBLIOGRAPHIC DATA

SHEET (See Instructions)
1. PUBLICATION OR REPORT NO. NBSIR-85/3195

2. Performing Organ. Report No.

3. Publication Date

July 1985

4. TITLE AND SUBTITLE

Heat Release Rate Characteristics of Some

Combustible Fuel Sources in Nuclear Power Plants

5. $A U T H O R(S)$

B. T. Lee

6. PERFORMING ORGANIZATION (If joint or other than NBS, see instructions)

7. Contract/Grant No.

NATIONAL BUREAU OF STANDARDS

DEPARTMENT OF COMMERCE

WASHINGTON, D.C. 20234

8. Type of Report \& Period Covered

9. SPONSORING ORGANIZATION NAME AND COMPLETE ADDRESS (Street, City, State, ZIP)

Nuclear Regulatory Commission

Washington, DC 20555

10. SUPPLEMENTARY NOTES

Document describes a computer program; SF-185, FIPS Software Summary, is attached.

11. ABSTRACT (A 200-word or less factual summary of most significant information. If document includes a significant bibliography or literoture survey. mention it here)

A major risk to a nuclear power plant is the possibility of serious fire. There is a need to know the heat release rate behavior of combustible fuels in the plant in order to help reduce the fire threat to these facilities. Heat release rate characteristics of cable tray fires and some of the associated potential external ignition sources are discussed. Existing correlations are given for determining the time to ignition and the subsequent heat release rate of spills and pools of flammable liquids. Approximate correlations are developed for heat release rate for trash fires as a function of fire size and for one particular cable tray array arrangement as a function of the type of cable. In addition, a scheme is given for calculating the heat release rate from wood fuel fires.

12. KEY WORDS (Six to twelve entries; alphabetical order; capitolize only proper names; and separate key words by semicolons) cable trays; fire safety; flammability; flammable liquids; heat release rate: ignition; liquid spills; nuclear power plants; pool fires; small-scale fire tests, trash; wood.

13. AVAILABILITY

Unlimited

For Official Distribution. Do Not Release to NTIS

$\square$ Order From Superintendent of Documents, U.S. Government Printing Office, Washington. D.C. 20402.

14. NO. OF

PRINTED PAGES

52

15. Price

[X Order From National Technical Information Service (NTIS), Springfield, VA. 2216I

$\$ 10.00$ 

